\title{
GIS-Based Assessment of Solar Energy Harvesting Sites and Electricity Generation Potential in Zambia
}

\author{
Mabvuto Mwanza and Koray Ulgen
}

\section{Contents}

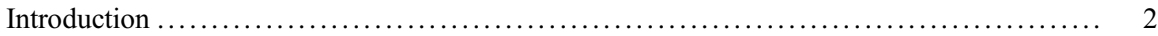

Geographical Description ............................................. 6

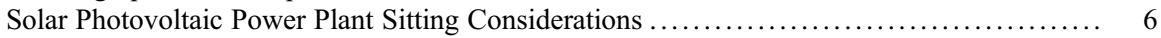

Environmental and Social Issues ........................................... 6

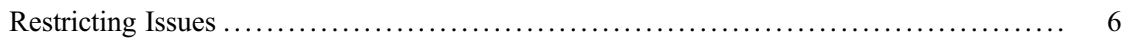

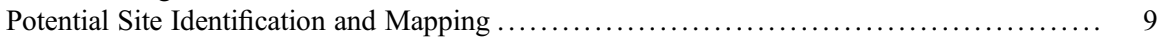

Solar PV Potential Site Identification and Mapping ............................. 9

Available Land Area .................................................... 13

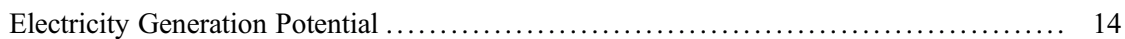

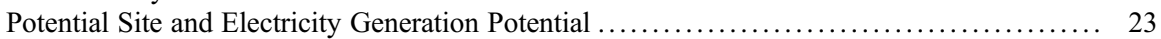

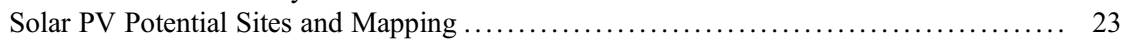

Available Suitable Land Area ............................................... 23

Electrical Power and Electricity Generation Potential ......................... 29

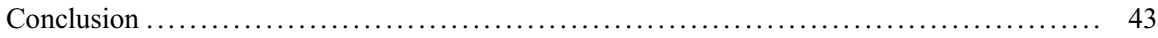

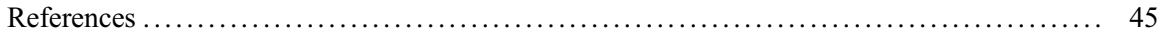

\section{Abstract}

Land and environment are some of limited nature resource for any particular country and requires best use. Therefore, for sustainable energy generation it is often important to maximize land use and avoid or minimize environmental and social impact when selecting the potential locations for solar energy harvesting. This chapter presents an approach for identifying and determining the potential sites and available land areas for solar energy harvesting. Hence, the restricting and enhancing parameters that influence sites selection based on international

M. Mwanza (殴

Department of Electrical \& Electronic Engineering, School of Engineering, University of Zambia, Lusaka, Zambia

K. Ulgen

Ege University, Solar Energy Institute, Bornova/Izmir, Turkey

e-mail: koray.ulgen@ege.edu.tr 
regulation have been imposed to the Laws of Zambia on environmental protection and pollution control legislative framework. Thus, both international regulations and local environmental protection and pollution control legislative have been used for identifying the potential sites and evaluating solar PV electricity generation potential in these potential sites. The restricting parameters were applied to reduce territory areas to feasible potential sites and available areas that are suitable for solar energy harvesting. The assessment involved two different models: firstly the assessment of potential sites and mapping using GIS, and secondly, evaluation of the available suitable land areas and feasible solar PV electricity generation potential in each provinces using analytical methods. The total available suitable area of the potential sites is estimated at $82,564.601 \mathrm{~km}^{2}$ representing $10.97 \%$ of Zambia's total surface area. This potential is equivalent to 10,240.73 TWh annual electricity generation potential with potential to reduce $\mathrm{CO}_{2}$ emissions in the nation and achieve SDGs. The identification of potential sites and solar energy will help improve the understanding of the potential solar energy can contribute to achieving sustainable national energy mix in Zambia. Furthermore, it will help the government in setting up tangible energy targets and effective integration of solar PV systems into national energy mix.

\section{Keywords}

Sustainable systems $\cdot$ Potential sites $\cdot$ Solar energy harvesting $\cdot$ Renewable energy $\cdot$ Zambia

\section{Introduction}

The purpose of meeting human basic needs and curbing climate change by reducing greenhouse gas emissions both at local and global levels has led to search for and establishment of energy policies for promoting renewable energy (Samuel and Owusu 2016; Sanchez-Lozano and García-Cascales 2014). The energy policies not only emphasized on promoting renewable energies but also on protecting natural resources and supporting natural environmental sustainability (Ivan 2015). Electricity generation from solar energy is in constant increase across the globe, but its share in the total energy production locally and globally still remains low as compared to fossil fuels. However, due to continual PV price decrease, increase in efficiency and maturity of technology in the last decades, feed-in tariffs including other incentives in many countries, has led to remarkable boom in photovoltaic (PV) technologies deployment and development both at utility-scale and residential levels across the globe (Robert 2014). According to International Energy Agency (IEA), the production of electricity from solar energy is expected to continue growing up to between 20\% and 25\% by 2050 (SEFI/UNEP 2009; Yassine 2011; Yassine and Adel 2012).

Despite of the remarkable boom in the application of solar PV technologies across the world, the application of these technologies in the electricity production in many developing countries like Zambia is still very negligible (Bowa 2017). However, 
there are only a few examples of small isolated solar systems used by communities, schools, companies, private households, hospitals, and health centers. These systems are often used to meet the daily energy needs and to cover up energy needs during load-shedding period (MMWED 2008; Bowa 2017). One of the largest solar systems installed by government so far through Rural Electrification Authorities (REA) was built in 2010 in Samfya district Northern Province (installed capacity of $60 \mathrm{~kW}$ ) (Bowa 2017). According to Bowa (2017), the estimated total installed capacity of solar photovoltaic-based power plants as of 2016 was more than 2 MW (small offgrid systems). Hence, despite of the country being located in most favorable solar belt (MMWED 2008) and receiving significant higher solar irradiation than most of world's largest solar energy utilizing countries, solar energy application for electricity generation has remained negligible. According to Meteorological Department of Zambia, the country has monthly average solar radiation incident rate of $5.5 \mathrm{kWh} /$ $\mathrm{m}^{2}$-day (Gauri 2013; MMWED 2008; Walimwipi 2012; IRENA 2013). The solar radiation intensity across the country varies with western part of country having the highest annual average of approximately $5.86 \mathrm{kWh} / \mathrm{m}^{2}$-day and the eastern part with the lowest of $5.68 \mathrm{kWh} / \mathrm{m}^{2}$-day as shown in Fig. 1. Therefore, Zambia has a favorable climate conditions for utilization of solar energy for both production of electricity and thermal use. The total annual average global solar radiation ranges from $1981 \mathrm{kWh} / \mathrm{m}^{2}$ in parts of North-Western, Eastern, Northern, Central, and Southern provinces to $2281 \mathrm{kWh} / \mathrm{m}^{2}$ in parts of Luapula, Northern, and Western provinces of Zambia as illustrated in Fig. 2.

In order to increase access to electricity for all, the Government of Republic of Zambia has set targets and plans to encourage deployment and development of renewable energy facilities across the country, with hydropower and solar energy based on photovoltaic technologies expected to experience the greatest growth. However, despite of several tools being available across the globe for estimating the solar energy potential for particular location, these tools do not fully take into consideration the environmental and social issues. In addition, the surface land areas and the natural environment are some of the world scarce natural resources that require selection of the best use of these rare resources (Ronald 2016). Therefore, in order to safeguard the natural environment and consider best use of available surface land areas, energy planning and site selection for promotion and deployment of renewable energy technologies in individual countries has become one of the most challenging aspect more especially in developing countries like Zambia.

In addition, unified planning and poor site selection for intermitted renewable energy source based power plant have resulted in mismatch between the grid capacity and PV power plant output during peak time in some parts of the world (Siheng et al. 2016; Ming 2015). On the other hand, arbitrary site selection and neglecting the transmission line available reserve margin in the procedure have resulted in some PV power plant exceeding the local transmission line reserve margin and grid unable to transmit the energy to the load centers during peak hours (Chinairn 2013; Aly Sanoh 2014; Quansah 2016). Therefore, preliminary estimation and mapping of potential sites, available areas, and technical energy yield potential for intermitted renewable energy source based power plant 


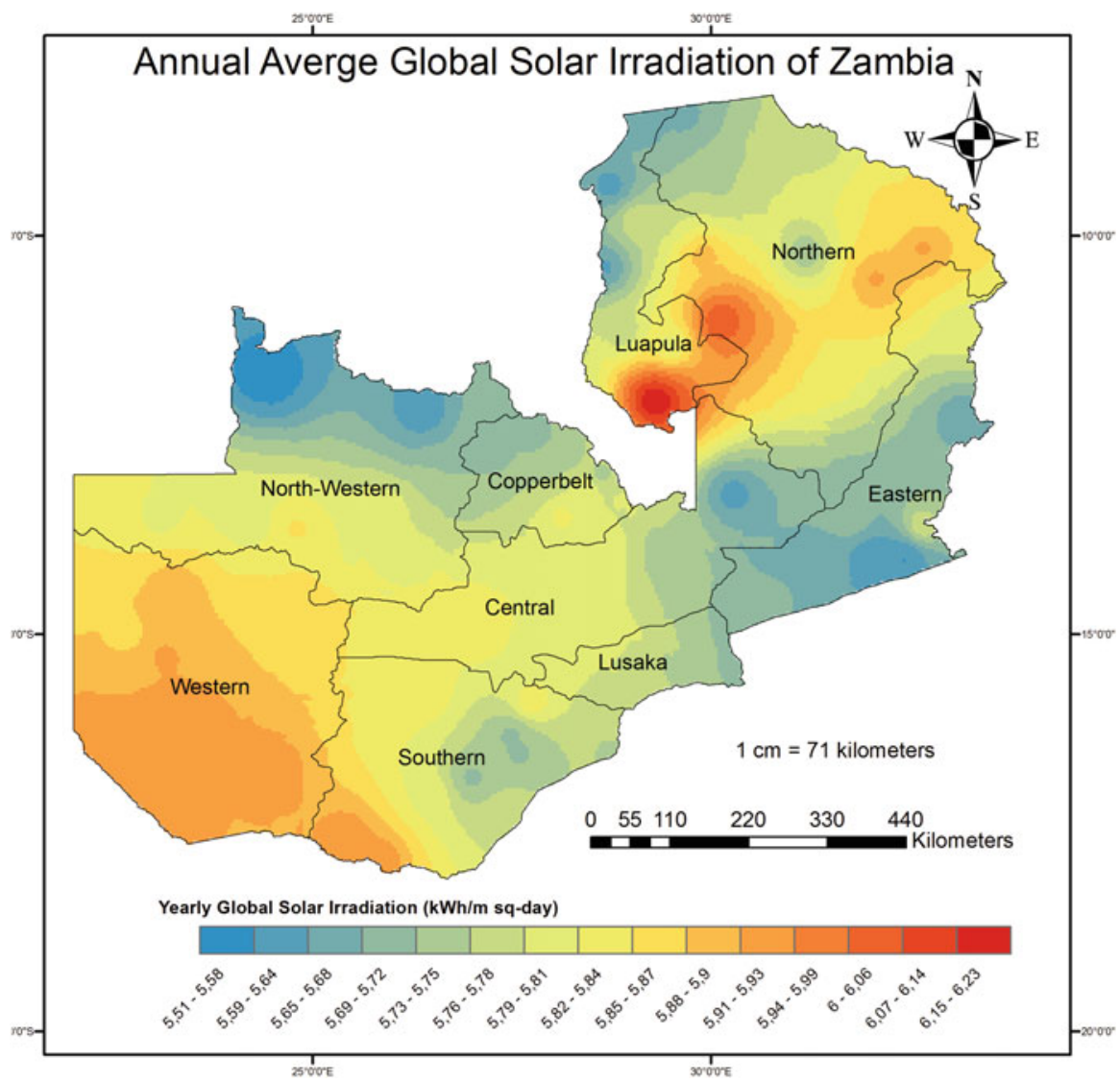

Fig. 1 Annual average horizontal solar irradiation

deployment while considering social acceptability and supporting natural environmental sustainability can be helpful to overcome these problems (Siheng et al. 2016). Doing so also helps to avoid and minimize potential negative environmental and social impacts associated with deployment of these technologies. The preliminary estimates and mapping of potential sites and technical energy yield potential for solar photovoltaic power plant development, however, have not been made in most developing countries like Zambia due to various reasons.

However, selection of potential site and evaluation of technical electricity generation potential requires a number of finer spatial resolution data, since not all locations of any particular country are suitable for deployment of these technologies due to local landscape terrain, climate, and environmental regulations (Suri 2005).

This chapter aims at providing a method for identifying and mapping a series of the potential sites and the available land areas suitable for solar energy harvesting in Zambia. The chapter further provides a method for assessing the electricity generation potential from solar energy based on commercially available solar photovoltaic 


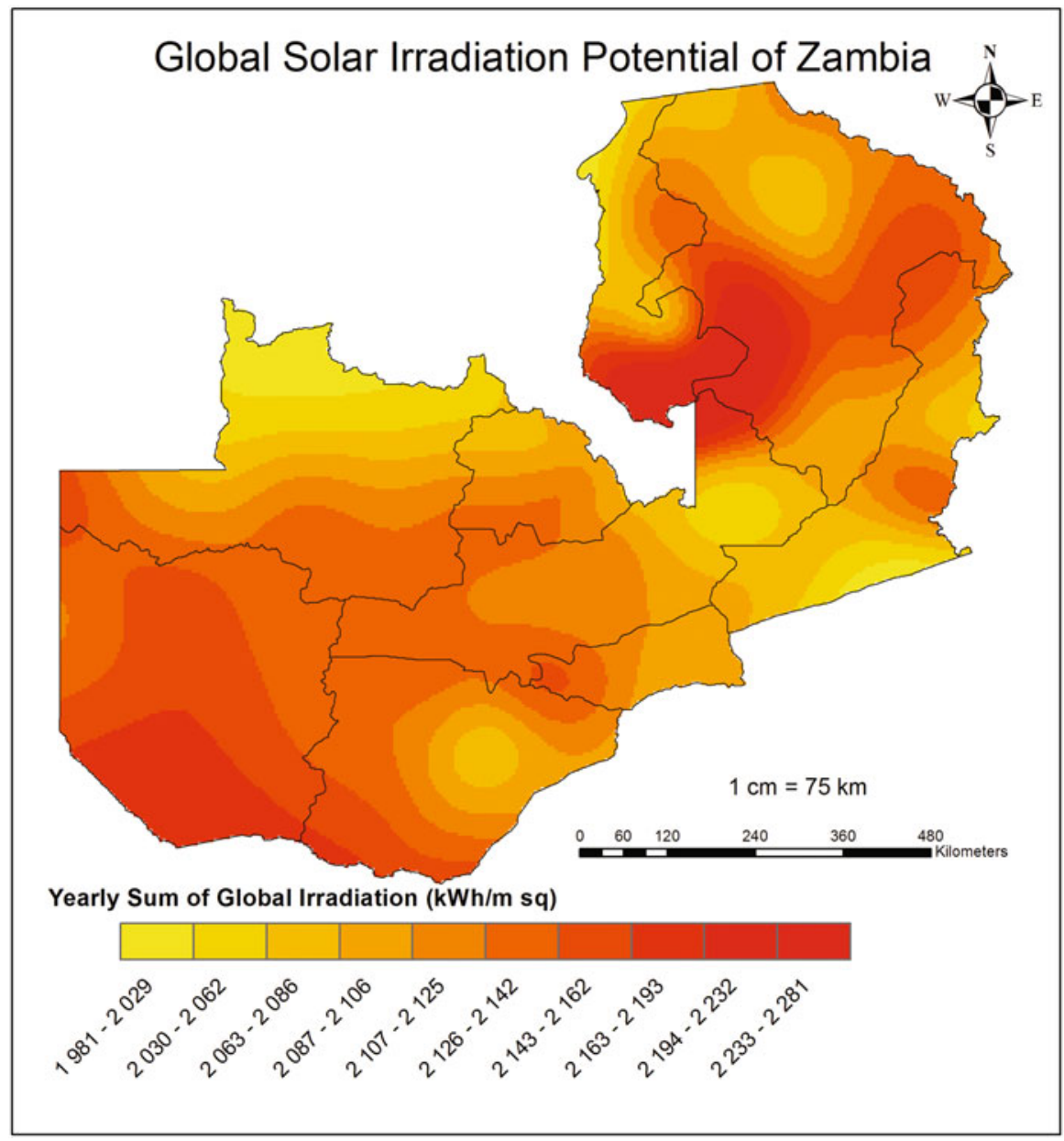

Fig. 2 Annual total global solar radiation intensity (Mwanza et al. 2016a)

technologies and available land areas. The evaluations in this chapter considered the modules of the solar PV systems mounted at optimal tilt position to the ground. The analysis focused on solar radiation, available areas, and typical energy that can be generated from the PV system considering the solar PV module characteristics and available solar radiation of the potential sites. The results of this study are important as it provides summarized information with regard to suitable potential sites, available land area, and technical electricity generation potential that can be attained from using solar photovoltaic technologies across Zambia. 


\section{Geographical Description}

Zambia is unique country endowed with variety and abundant nature resources, such as wildlife resources, watercourse resources, forests resources, minerals resources, and renewable energy resources. Its abundant renewable energy resources such as solar energy are heavily untapped. The country is also blessed with unique climate and geography of flatland in most part of the country. It is situated between latitudes $8^{0}$ and $18^{\circ}$ south of the equator and longitudes $22^{\circ}$ and $34^{\circ}$ east of prime meridian. The country is landlocked by eight countries, Zimbabwe and Botswana to the South, Angola to the West, Democratic Republic of Congo and Tanzania to the North, Malawi and Mozambique to the East, and Namibia to the Southwest (Mwanza et al. 2016a).

\section{Solar Photovoltaic Power Plant Sitting Considerations}

\section{Environmental and Social Issues}

Solar energy is clean, free, and unlimited renewable energy sources that can be used for variety of purposes including pumping water for irrigations, drying and preparing food, and most importantly for electricity generation. However, just like any other alternative energy supply option, solar photovoltaic technology deployments at utility-scale are not free from imposing negative effects on both the environment and society (www.energy.gov) (Wang and Prinn 2010; Union of Concerned Scientists 2015). Most of these effects depend on development size, site, and the type of technology deployed and also site selection and environmental guidance procedure. The environmental and social impacts associated with renewable energy technology development are mainly grouped as listed in Table 1 (Ahmed Aly 2017; Turlough 2017; Shifeng and Sicong 2015; Kaoshan et al. 2015; Fylladitakis 2015; Saidur et al. 2011; Gipe 1995; Interior Department 2010; Damon and Vasilis 2011; U.S 2016; Geoffrey and Tidwell 2013; England 2011; Tsoutsos 2005, 2009).

\section{Restricting Issues}

The potential impacts associated with utilization of renewable energy technology have potential to hinder or delay deployment and development of solar photovoltaic technologies or facilities in potential sites. Table 2 and Figs.3, 4, 5, 6, 7, 8, 9, 10, 11 , and 12 list solar PV systems deployment restricting issues that have, among others, been considered for inclusion, as appropriate, in the available land area, technical electricity generation potential, and potential sites assessment for sustainable solar photovoltaic facilities development in Zambia based on highlighted environmental and social impacts (www.energy.gov; Abdolvahhab Fetanat 2015; Alami et al. 2014; Ahmed et al. 2017; Arthur Bossavy 2016; Addisu and Mekonnen 2015; Marcos Rodriques 2010; Anthony Lopez 2012). Restricting criteria data are features that 
Table 1 Summarized environmental and social impacts induced by solar photovoltaic power Plants

\begin{tabular}{|c|c|c|c|}
\hline $\begin{array}{l}\text { Type of } \\
\text { impact }\end{array}$ & Causes & Factors contributing & Effects \\
\hline $\begin{array}{l}\text { Noise } \\
\text { pollution }\end{array}$ & $\begin{array}{l}\text { Inverter noise due to } \\
\text { internal electronics, } \\
\text { transformer noise, } \\
\text { construction noise }\end{array}$ & $\begin{array}{l}\text { Air temperature, } \\
\text { humidity, ground } \\
\text { surface material, } \\
\text { background noise, } \\
\text { heavy machinery, } \\
\text { human activity }\end{array}$ & $\begin{array}{l}\text { Sleep disturbance, } \\
\text { hearing losses, } \\
\text { headaches, irritability, } \\
\text { fatigue, constrict } \\
\text { arteries, weaken } \\
\text { immune systems, } \\
\text { annoyance, or } \\
\text { dissatisfaction }\end{array}$ \\
\hline $\begin{array}{l}\text { Air and water } \\
\text { pollution }\end{array}$ & $\begin{array}{l}\text { PV module: Toxic } \\
\text { materials, heavy } \\
\text { machinery \& } \\
\text { transformers: Oil, } \\
\text { switchgear breaker gas } \\
\mathrm{SF}_{6} \text {, ground clearing } \\
\text { and grading }\end{array}$ & $\begin{array}{l}\text { Fire, module cracking, } \\
\text { leaking machinery due } \\
\text { to poor maintenance, } \\
\text { leakages in switchgear, } \\
\text { transformers, \& } \\
\text { machinery, access roads } \\
\text { \& ground preparing }\end{array}$ & $\begin{array}{l}\text { Death, injuries, loss of } \\
\text { ecosystem, } \\
\text { contamination of soil, } \\
\text { water, and air }\end{array}$ \\
\hline Water use & $\begin{array}{l}\text { Periodic maintenance: } \\
\text { PV module surface } \\
\text { cleaning, construction } \\
\text { activity, dust abatement } \\
\text { activities }\end{array}$ & $\begin{array}{l}\text { Dust, wind, location, } \\
\text { size of facility, system } \\
\text { performance, unpaved } \\
\text { roads }\end{array}$ & $\begin{array}{l}\text { Reduced underground } \\
\text { water recharge, reduced } \\
\text { surface water flow, } \\
\text { agriculture water } \\
\text { problem, wildlife water } \\
\text { problem, human water } \\
\text { problem }\end{array}$ \\
\hline $\begin{array}{l}\text { Climate } \\
\text { Change \& } \\
\text { Greenhouse } \\
\text { gas (GHG) } \\
\text { emissions }\end{array}$ & $\begin{array}{l}\text { Concrete and steel for } \\
\text { PV array mounting } \\
\text { foundations }\end{array}$ & $\begin{array}{l}\text { Size of PV array, } \\
\text { location of facility }\end{array}$ & $\begin{array}{l}\mathrm{CO}_{2} \text { emission; global } \\
\text { warming }\end{array}$ \\
\hline $\begin{array}{l}\text { Wildlife \& } \\
\text { Habitat loss }\end{array}$ & $\begin{array}{l}\text { Excavation, grading, } \\
\text { ground clearing, road \& } \\
\text { electrical grid } \\
\text { construction }\end{array}$ & $\begin{array}{l}\text { Location, landscape } \\
\text { topography, size of } \\
\text { facility, distance to road } \\
\text { and electrical grid }\end{array}$ & $\begin{array}{l}\text { Loss of feeding, nesting } \\
\text { or roosting grounds for } \\
\text { animals, birds, } \\
\text { ecosystem disturbance, } \\
\text { wildlife reduction }\end{array}$ \\
\hline Visual impact & $\begin{array}{l}\text { Distance to residential } \\
\text { areas, size of facility, } \\
\text { night lights at power } \\
\text { plant, human perception }\end{array}$ & $\begin{array}{l}\text { Scenic backgrounds, } \\
\text { local landscape } \\
\text { topography, local } \\
\text { landscape between solar } \\
\text { plant and viewers, } \\
\text { location of solar farm, } \\
\text { color of PV panels, } \\
\text { layout of solar farm; } \\
\text { irregular or regular, } \\
\text { clear skies }\end{array}$ & $\begin{array}{l}\text { Aesthetic effects, public } \\
\text { health, negative } \\
\text { perception of solar } \\
\text { energy technologies, } \\
\text { visual effect }\end{array}$ \\
\hline
\end{tabular}


Table 1 (continued)

\begin{tabular}{|c|c|c|c|}
\hline $\begin{array}{l}\text { Type of } \\
\text { impact }\end{array}$ & Causes & Factors contributing & Effects \\
\hline $\begin{array}{l}\text { Land use/ } \\
\text { Soil \& Land } \\
\text { Degradation, } \\
\text { fugitives dust }\end{array}$ & $\begin{array}{l}\text { Power grid \& access } \\
\text { road construction, PV } \\
\text { array foundation } \\
\text { excavation, removal of } \\
\text { surface plants, } \\
\text { wastewater and oil from } \\
\text { construction machinery, } \\
\text { excess wastes from } \\
\text { construction: Plastics, } \\
\text { metal, glues, \& inks }\end{array}$ & $\begin{array}{l}\text { Layout of solar PV } \\
\text { farms, location of solar } \\
\text { PV farm, landscape } \\
\text { topography, type of PV } \\
\text { technology, tilt angle of } \\
\text { modules, distance to } \\
\text { access road and } \\
\text { electrical grid, office } \\
\text { wastes }\end{array}$ & $\begin{array}{l}\text { Deforestation, soil } \\
\text { erosion, loss of habitat, } \\
\text { landslide, floods, air } \\
\text { and water pollution, } \\
\text { ecosystem disturbance, } \\
\text { fugitive dust }\end{array}$ \\
\hline
\end{tabular}

Table 2 Restricting issue datasets

\begin{tabular}{|c|c|c|}
\hline $\begin{array}{l}\text { Type of impact eliminated, } \\
\text { minimized or avoided }\end{array}$ & $\begin{array}{l}\text { Site } \\
\text { descriptions }\end{array}$ & Detail nature of sites descriptions \\
\hline Water use, Wildlife \& Habitat Loss & Wildlife sites & National parks and game reserves \\
\hline $\begin{array}{l}\text { Visual impact, Noise Pollution \& } \\
\text { Land use/degradation, fugitives dust }\end{array}$ & $\begin{array}{l}\text { Community } \\
\text { interest sites }\end{array}$ & $\begin{array}{l}\text { Airfields, historical sites, } \\
\text { archaeological sites, traditional and } \\
\text { cultural heritage sites, national } \\
\text { monuments sites and tourism sites, } \\
\text { religious significance sites }\end{array}$ \\
\hline Water use, land use/degradation & $\begin{array}{l}\text { Agriculture } \\
\text { sites }\end{array}$ & $\begin{array}{l}\text { Crop areas and potential agriculture } \\
\text { areas }\end{array}$ \\
\hline $\begin{array}{l}\text { Fugitive dust, water use, air/Noise } \\
\text { Pollution \& Visual Impact, land use }\end{array}$ & Settlement sites & $\begin{array}{l}\text { Rural/urban and residential areas: } \\
\text { Towns, cities, villages, and areas } \\
\text { used extensively for recreation and } \\
\text { aesthetic reasons }\end{array}$ \\
\hline $\begin{array}{l}\text { Water pollution, Wildlife \& Habitat } \\
\text { Loss, land degradation }\end{array}$ & $\begin{array}{l}\text { Surface water } \\
\text { bodies and } \\
\text { surrounding } \\
\text { sites }\end{array}$ & $\begin{array}{l}\text { Rivers, lakes, streams, waterfalls, } \\
\text { and wetlands }\end{array}$ \\
\hline $\begin{array}{l}\text { Land degradation, Wildlife \& } \\
\text { Habitat Loss }\end{array}$ & Landscape & $\begin{array}{l}\text { Land elevation and slope } \\
\text { ( }>5 \text { degrees), areas prone to flooding } \\
\text { and natural hazards, zones prone to } \\
\text { erosion or desertification, zones of } \\
\text { high biological diversity, areas } \\
\text { supporting populations of rare and } \\
\text { endangered species, }\end{array}$ \\
\hline $\begin{array}{l}\text { Land use, Wildlife \& Habitat Loss, } \\
\text { fugitive dust, water, air and soil } \\
\text { pollution, visual impact }\end{array}$ & Right of way & $\begin{array}{l}\text { Transmission, roads and railroads } \\
\text { network right of way }\end{array}$ \\
\hline $\begin{array}{l}\text { Wildlife \& Habitat Loss, climate } \\
\text { Change \& Greenhouse gas (GHG) } \\
\text { emissions, land degradation }\end{array}$ & $\begin{array}{l}\text { Forest and } \\
\text { surrounding } \\
\text { sites }\end{array}$ & $\begin{array}{l}\text { Forests: Low need-leaved deciduous } \\
\text { forest and moderate evergreen } \\
\text { deciduous forest, shrub-lands: } \\
\text { Closed to open shrub-land and open } \\
\text { shrub-land, grassland: Sparse } \\
\text { grassland, indigenous forest }\end{array}$ \\
\hline
\end{tabular}




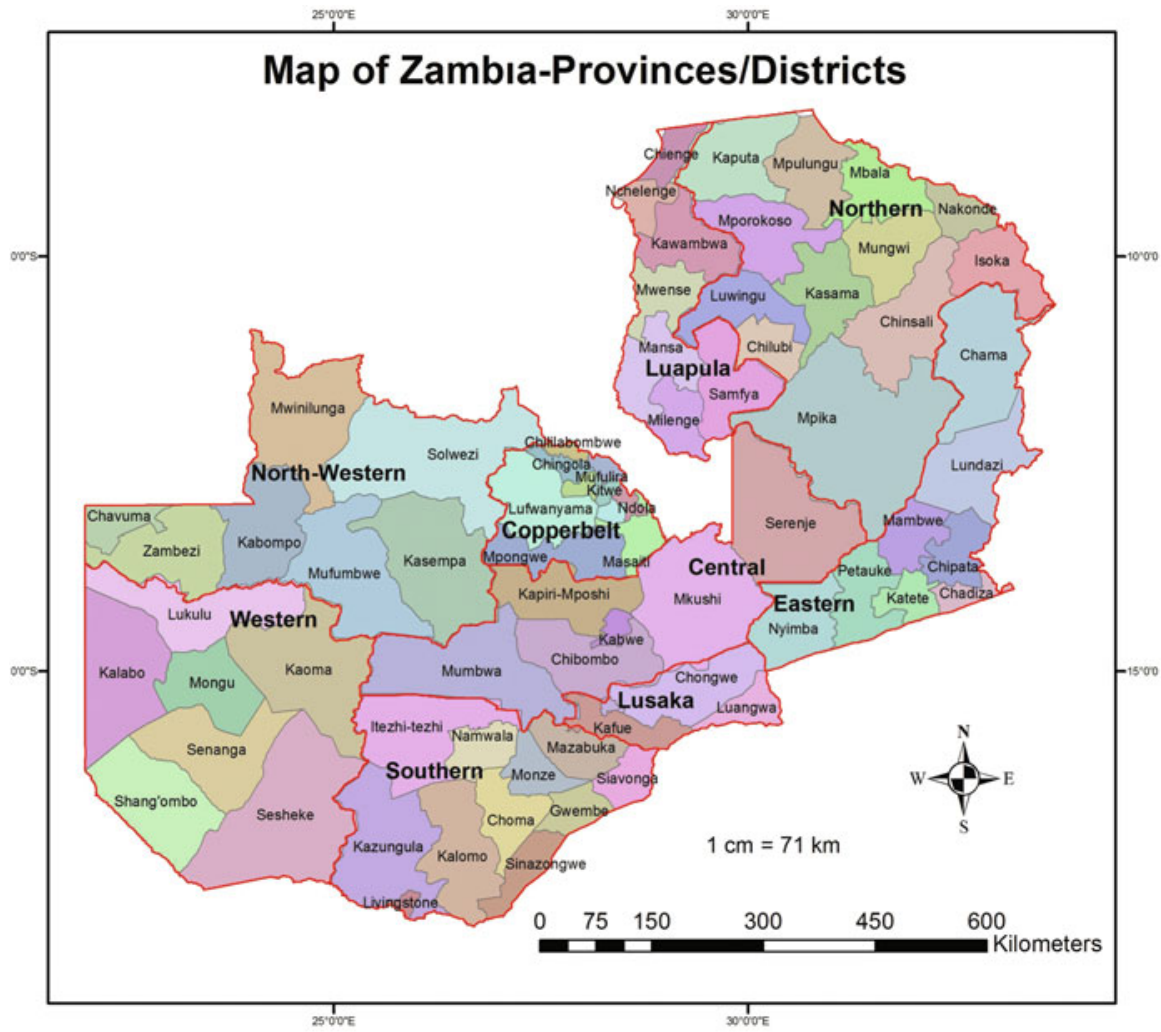

Fig. 3 Administrative boundary map

pose restrictions or limitations, that is, unsuitable or not preferred areas based on legislative laws of the country and nature.

\section{Potential Site Identification and Mapping}

\section{Solar PV Potential Site Identification and Mapping}

In order to assess the potential sites suitable for utility-scale solar photovoltaic deployment based on literatures surveyed and the laws of Zambia on environmental for development of any industry or plant on a particular site and restrictions datasets summarized in Table 2. Thus, the following environmental and social impacts and issues illustrated in Table 3, among others, are considered for inclusion, as appropriate, in the selection of suitable sites for solar energy facilities (ECZ 1994).

These maps included land elevation map (DEM), land use/cover layer map, town and village location map, community interest sites map, national parks map, surface water bodies map, roads and railway map, study area boundaries, and transmission 


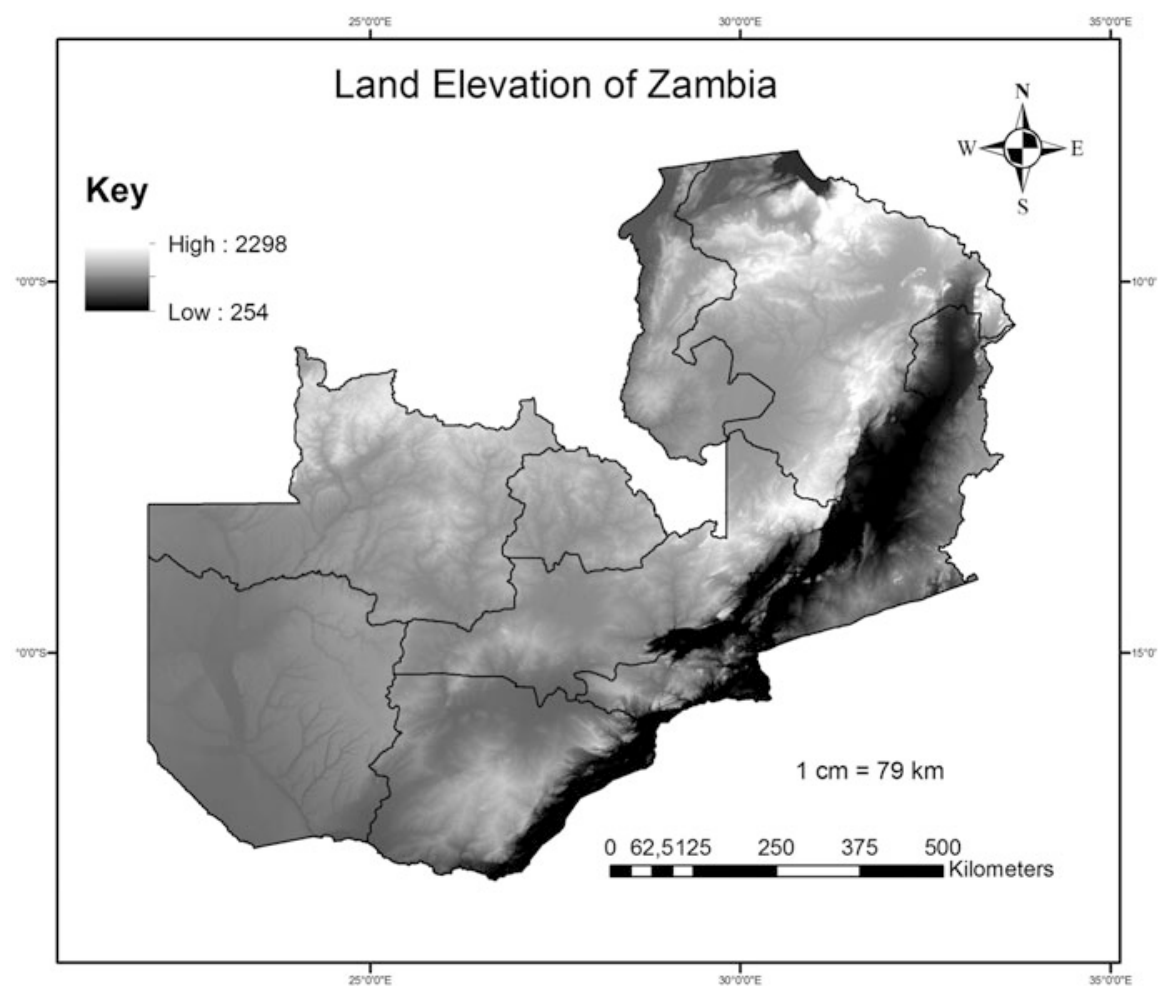

Fig. 4 Land digital elevation map

line maps (Nazli Yonca 2010; Sanchez Lozano et al. 2013, Brewer 2014, Chao-Rong Chen 2014, Charabi and Gastli 2011, Lopez 2012, Janke 2010; Uyan 2013). The rationale used for each restrictions are as follows:

- Land Use/Cover (C6, C9): This dataset has 10 classes including bare land, closed to open shrubland, open shrubland, sparse grassland, croplands, urban settlement, water courses, wetland, and forest sites; low need-leaved deciduous forest and moderate evergreen forest. For deployment of solar PV power plants only bare lands, sparse grassland and open shrubland were considered suitable due to easy accessibility considering an emerging economy and also to reduce land clearing costs.

- Wildlife Sites (C2): this dataset considers areas such as national parks, game reserves, and other natural resources since development in these sites will have adverse impact on birds, animals, and ecology, thus any construction in these areas may face public and international resistance. Therefore, these areas and the surrounding areas within the buffer of $2 \mathrm{~km}$ were considered not suitable (Nazli Yonca 2010). 


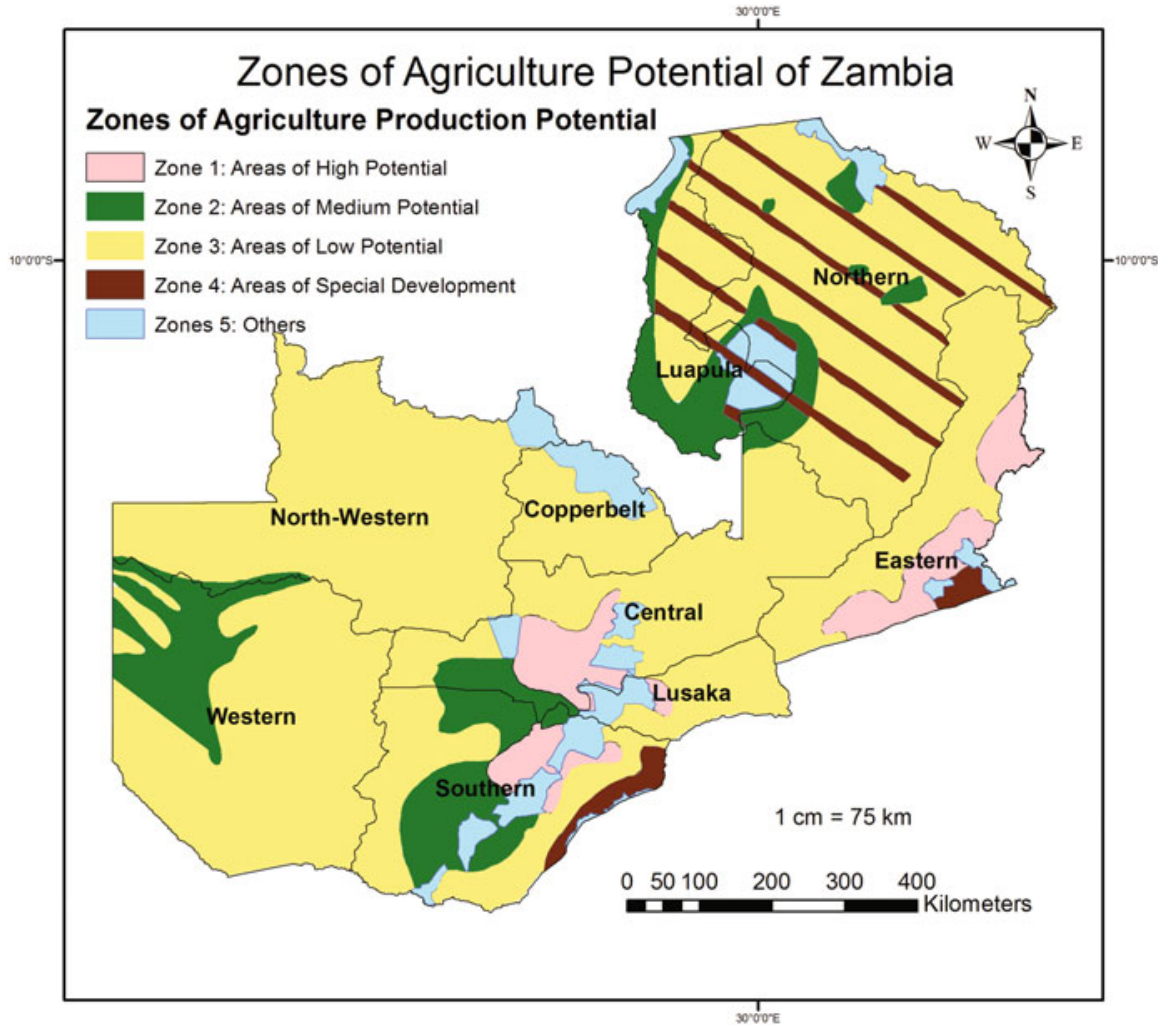

Fig. 5 Zones of agriculture production potential

- Settlement and Community Interest Sites (C4, C1): The dataset consists of settlement areas for both rural and urban such as airfields, airports, towns, villages, and other dwelling areas and community interest sites. Here a buffer of $3 \mathrm{~km}$ is considered to avoid aforementioned impacts and increase public safety and acceptance. All areas outside the buffer were considered suitable (Joss and Watson 2015).

- Land Elevation (C7): As it is expected that no one will install solar PV power plants in gorges or higher elevation due to construction costs. Thus, this dataset considered all higher and lower elevations such as mountains and gorges with steeper slopes above $5^{0}$ as unsuitable areas.

- Surface Water Bodies (C8): In this dataset all surface water bodies such as rivers, streams, lakes, including waterfalls, and wetlands were considered as protected areas in order to avoid water pollution. Thus, a buffer of $2 \mathrm{~km}$ was considered with all areas outside buffer being suitable.

- Roads and Railways Network (C3): The dataset considers roads and railway network to be restriction since no one is supposed to build on roads or railway and also for the safety of the public. Hence, a $0.5 \mathrm{~km}$ buffer has been considered in 


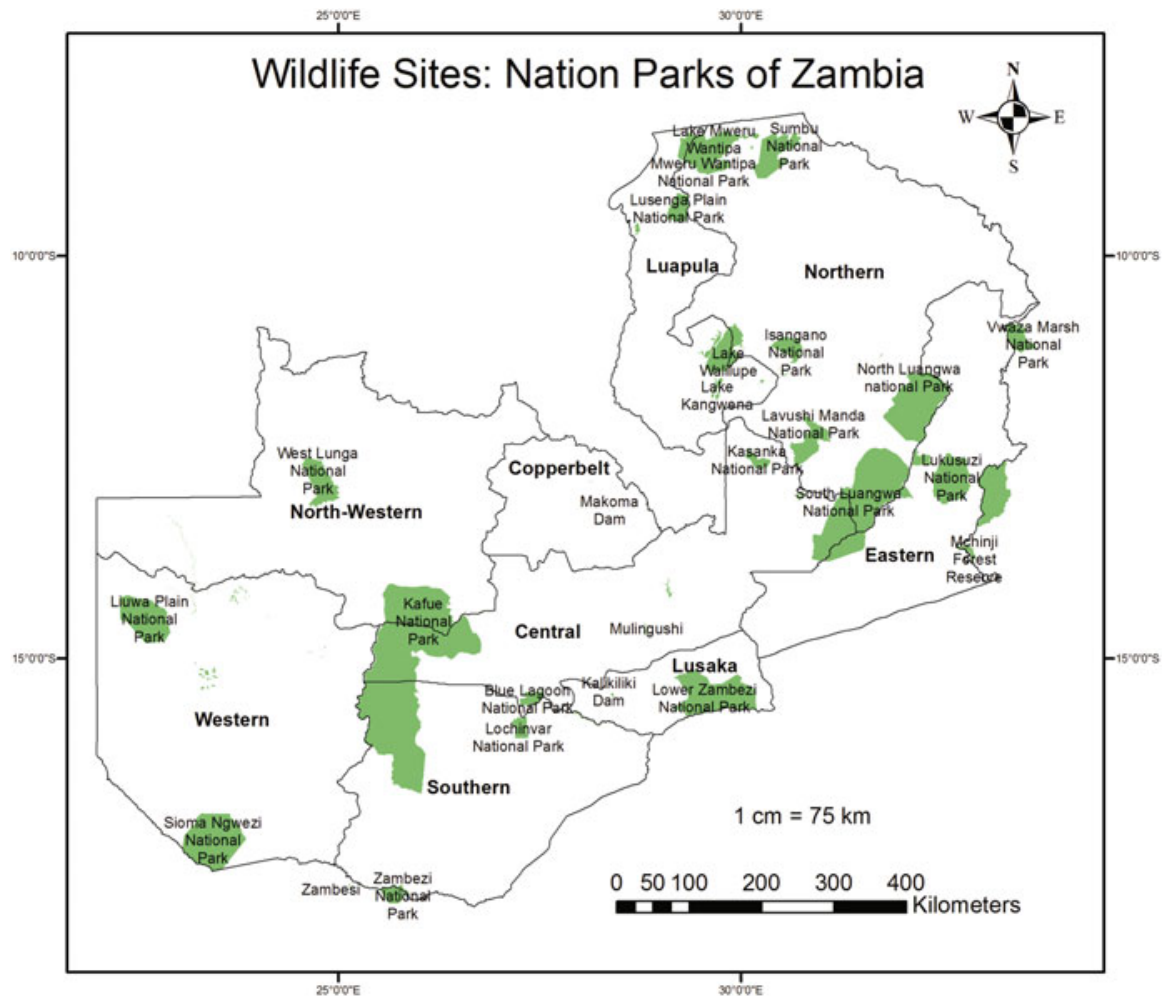

Fig. 6 Wildlife areas: national parks

order to increase public safety and also reduce cost of constructing access road which usually leads to land use/degradation, wildlife and habitat loss, fugitive dust, and air and soil pollution to the site and surrounding areas. Thus, the areas outside the buffer are considered suitable.

- Transmission Line Network (C5): In this dataset the right of way for transmission line were considered as unsuitable area for solar PV power plants, thus a $0.5 \mathrm{~km}$ buffer was used. Any areas within the buffer were considered unsuitable. The $0.5 \mathrm{~km}$ buffer were considered so that the cost of constructing new transmission lines is reduced, but at the same time to avoid conflict with right of way for transmission lines and avoid land use/degradation, wildlife and habitat loss, fugitive dust, water, and air and soil pollution to the site and surrounding areas.

After creating buffers, and changing some features from vector to raster, in order to evaluate available areas and identify/map feasible potential sites, the created buffers for the restricting layers were overlaid on each other using GIS spatial analysis. Figure 13 below shows the summarized analysis procedure. 


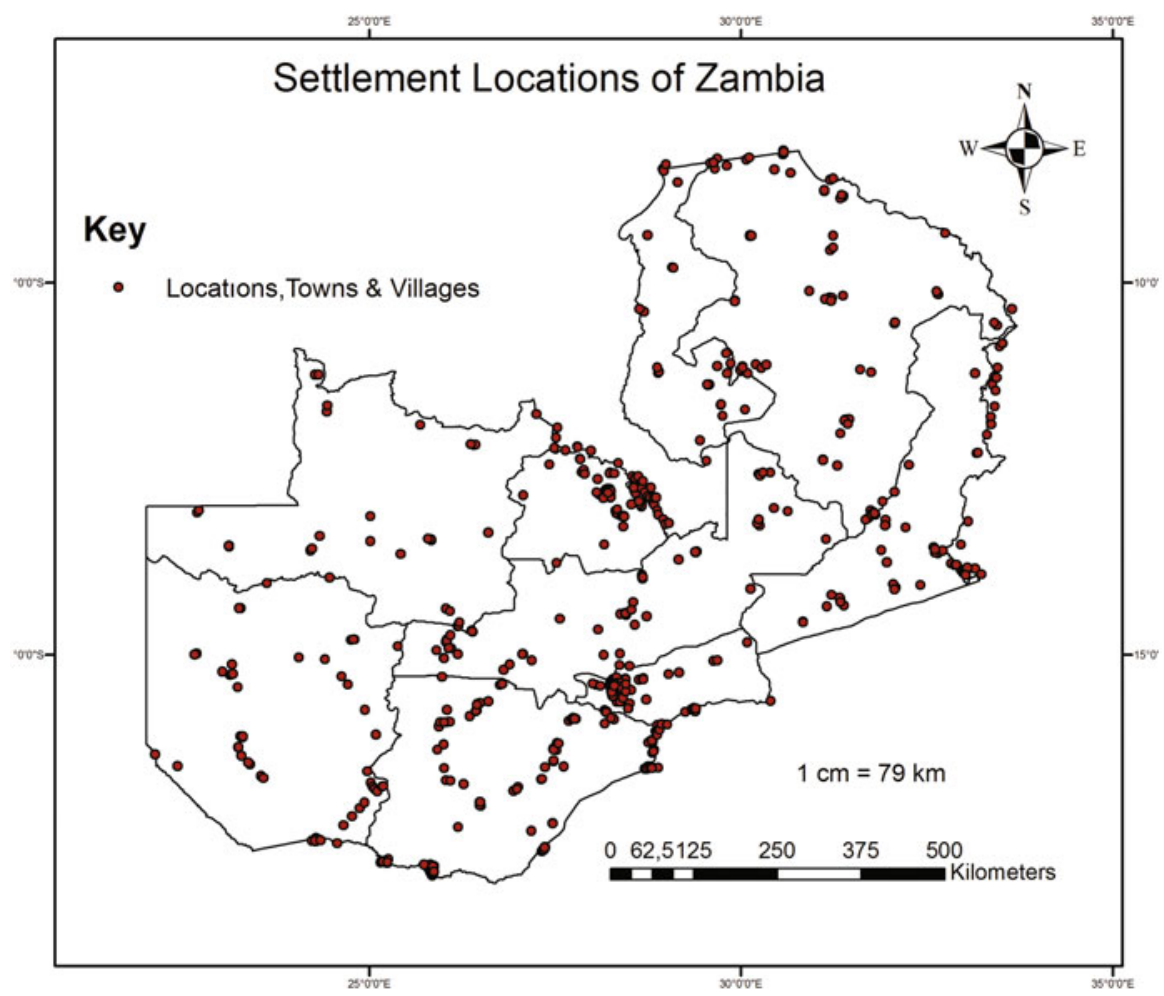

Fig. 7 Settlement and community interest sites

\section{Available Land Area}

In order to estimate the available suitable areas for solar photovoltaic power plant development based on aforementioned restrictions issues, a new factor called Area Suitability factor $f_{\mathrm{SF}}$ was introduced. It is defined as the ratio of total grid cells of suitable surface area to the total cells of the study surface area. The factor is estimated based on study area grid cells; here the total grid cells for study surface area are evaluated considering the sum of restricted and suitable surface areas' cells. Hence the factor depends on the ratio of available suitable area and surface area of the study area and it is calculated using the expression below.

$$
f_{S F}=\left(\frac{C_{C S A}}{C_{C S A}+C_{C R A}}\right)=\frac{C_{C S A}}{C_{T S S A}}
$$

where $\mathrm{C}_{\mathrm{CSA}}$ is the total number of cells of suitable areas, $\mathrm{C}_{\mathrm{CRA}}$ is the total number of cells of restricted areas, and $\mathrm{C}_{\mathrm{TSSA}}$ is total number of cells of study area.

Therefore, the total available suitable land areas for each district and for Zambia were evaluated using expression 2 given below 


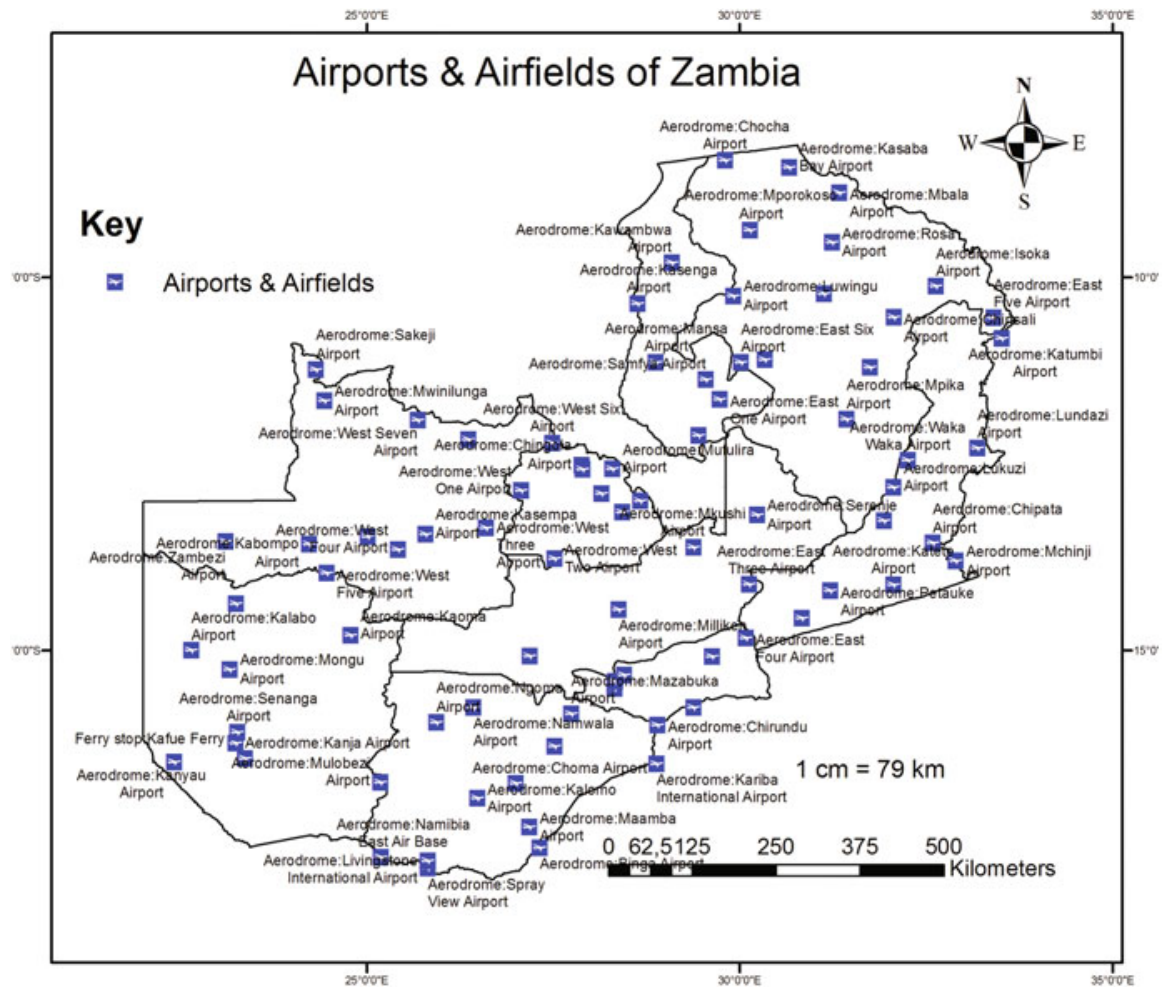

Fig. 8 Airports and airfield

$$
A_{A D S}=f_{S F} \cdot A_{T S A}
$$

where $A_{A D S}$ is total available suitable areas $\left(\mathrm{km}^{2}\right)$, and $A_{T S A}$ is total surface area of the study area $\left(\mathrm{km}^{2}\right)$.

\section{Electricity Generation Potential}

\section{Solar Energy Potential in Zambia}

According to the literature and data undertaken by Meteorological Department of Zambia, the country has a significant potential of solar energy for both electrical power production and thermal from solar energy technologies. The country has average peak sunshine of about 6-8 hours per day and monthly average solar radiation of $5.5 \mathrm{kWh} / \mathrm{m}^{2}$-day throughout the year (MMWED 2008; Walimwipi 2012). According to International Renewable Energy Agency (IRENA 2012), the country has the highest total yearly solar radiation of $2,750 \mathrm{kWh} / \mathrm{m}^{2}$-year with the highest average temperature of $30{ }^{\circ} \mathrm{C}$, which presents good opportunity for solar systems deployment (IRENA 2012). 


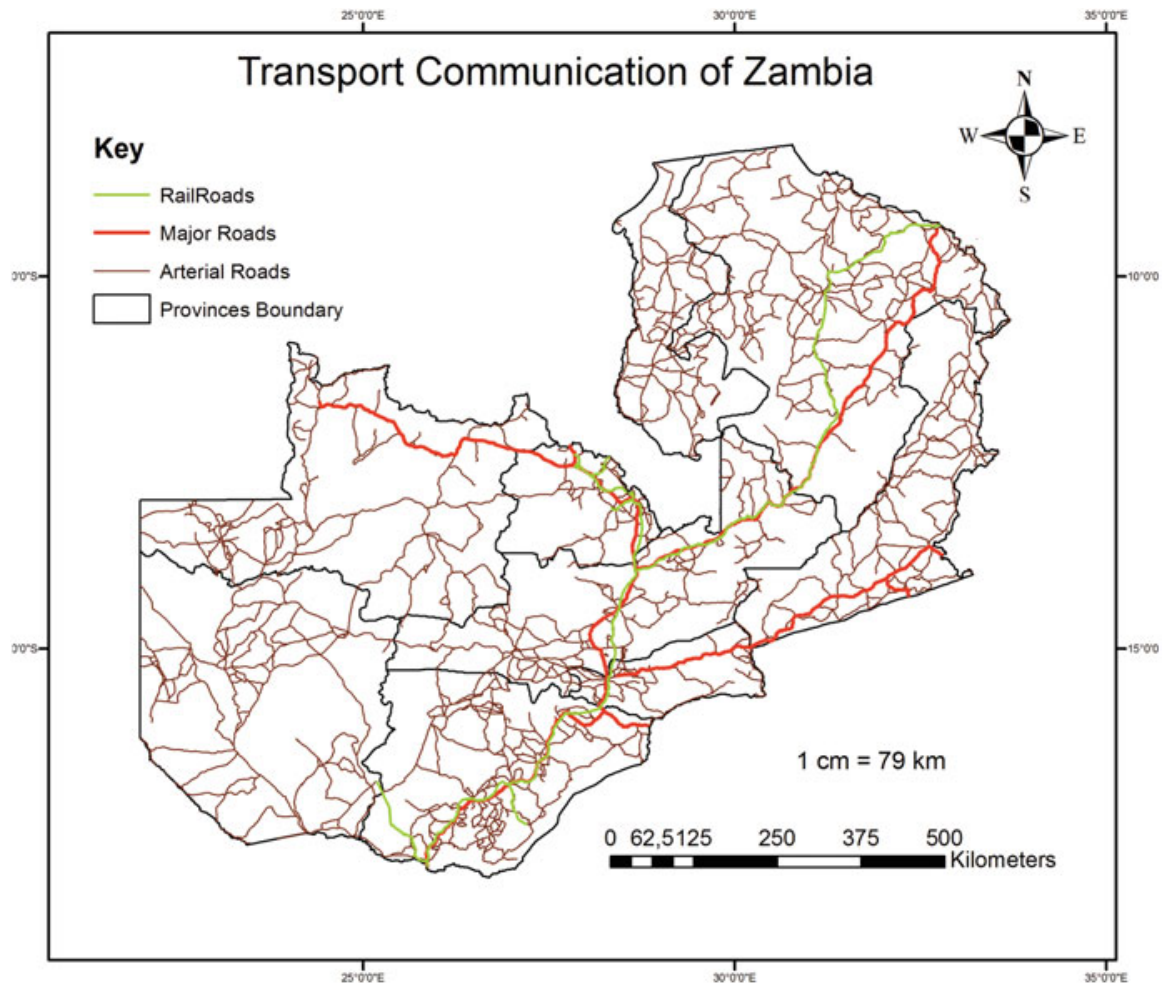

Fig. 9 Road and railroad networks

\section{Performance of PV System}

In order to evaluate the performance of grid connected PV power plants, the following performance indices are normally used: yields, normalized losses, and system efficiencies, performance ratio, and capacity factor - (British Standard 1998). However, in this chapter final yield, performance ratio and capacity factor have been adopted for analyzing the PV system performance of the various types of PV technologies commercially available on the market (Table 3) considering Zambia's weather condition. In addition, several PV technologies have been considered in the evaluation of technical electricity generation and power potential: firstly, because the energy generation by PV power plants with same peak power and receiving same amount of solar irradiation differs depending on the type of technology employed in the power plants, and secondly, the amount of peak power that can be installed at a given land area differ with PV technologies as shown in Table 4. Hence, it can be concluded that the type of cell technology has greater influence in the amount of land area needed for a peak power installation, the higher the efficiency the lower the land requirements for the peak power capacity installation (Martin-Chivelet 2016). 


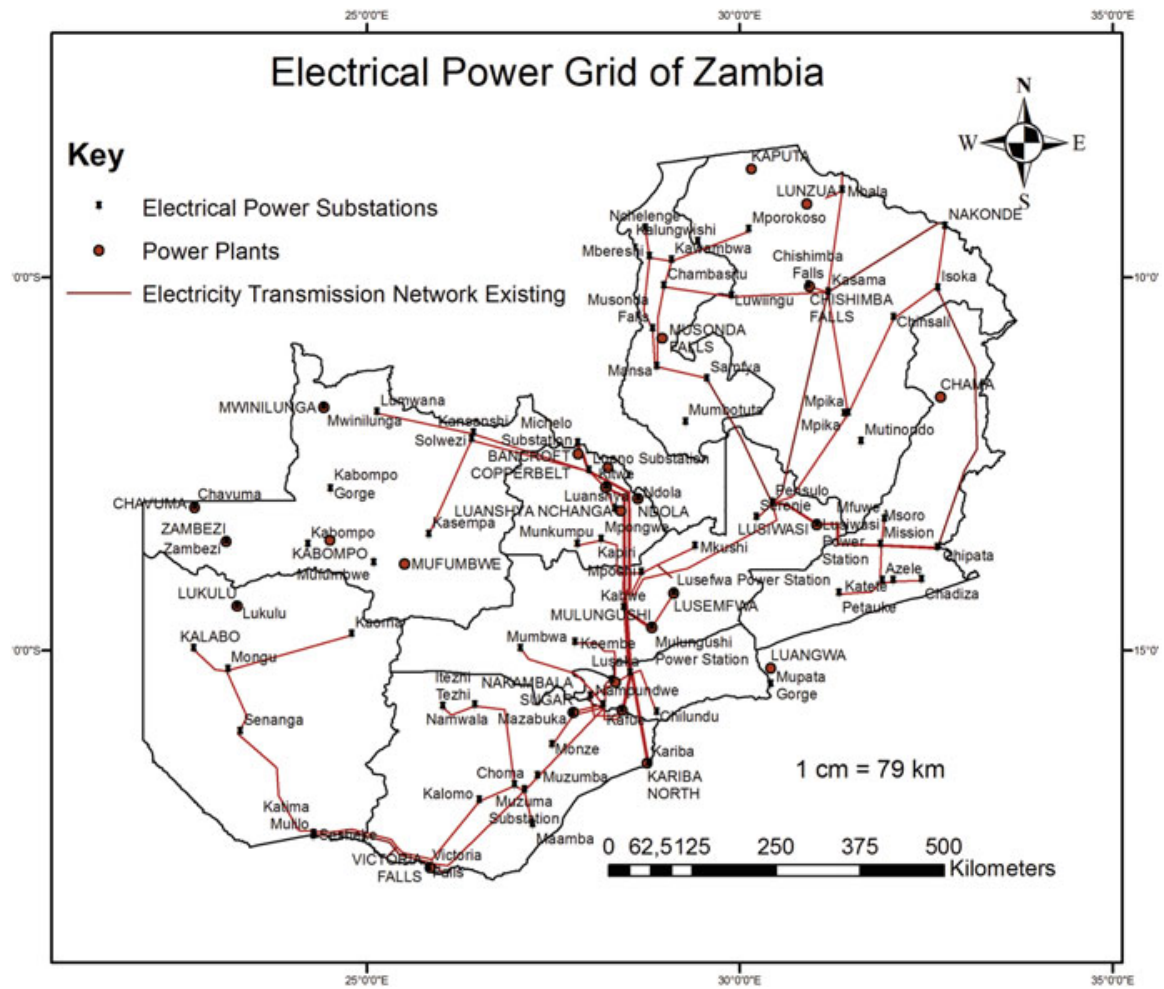

Fig. 10 Existing electrical network

\section{Energy Model of PV Array}

The solar energy resources are the key determinants of PV system electricity generation (IRENA 2012). The higher the solar energy resources, the more output yield of a PV systems per kilowatt. However, higher temperatures, dust, shading, balance of system inefficiencies, and PV technology characteristics have negative impact on the PV system energy yield (Didler 2012). Therefore, the electricity generated and supplied to grid by PV system considering these negative impacts has been estimated using Eq. 3:

$$
E_{A}=A_{P V} \cdot H_{R} \cdot \eta_{P}\left(1-\lambda_{p}\right)\left(1-\lambda_{C}\right)
$$

where $\mathrm{E}_{\mathrm{A}}$ is energy output of $\mathrm{PV}$ system (MWh/year), $\mathrm{H}_{\mathrm{R}}$ is solar radiation on the surface of module ( $\mathrm{kWh} / \mathrm{m}^{2}$-day), $\mathrm{A}_{\mathrm{PV}}$ is $\mathrm{PV}$ system active area $\left(\mathrm{m}^{2}\right), \eta_{\mathrm{P}}$ is module efficiency under STC condition, $\lambda_{\mathrm{p}}$ is miscellaneous module losses due to dusty covering, and $\lambda_{\mathrm{C}}$ is losses due to power conditioning unit and cable losses. Module efficiency is a function of its nominal efficiency, $\eta_{\mathrm{r}}$, which is measured at STC $\mathrm{T}_{\mathrm{r}}=25^{\circ} \mathrm{C}$ (Didler 2012). İt has been calculated as: 


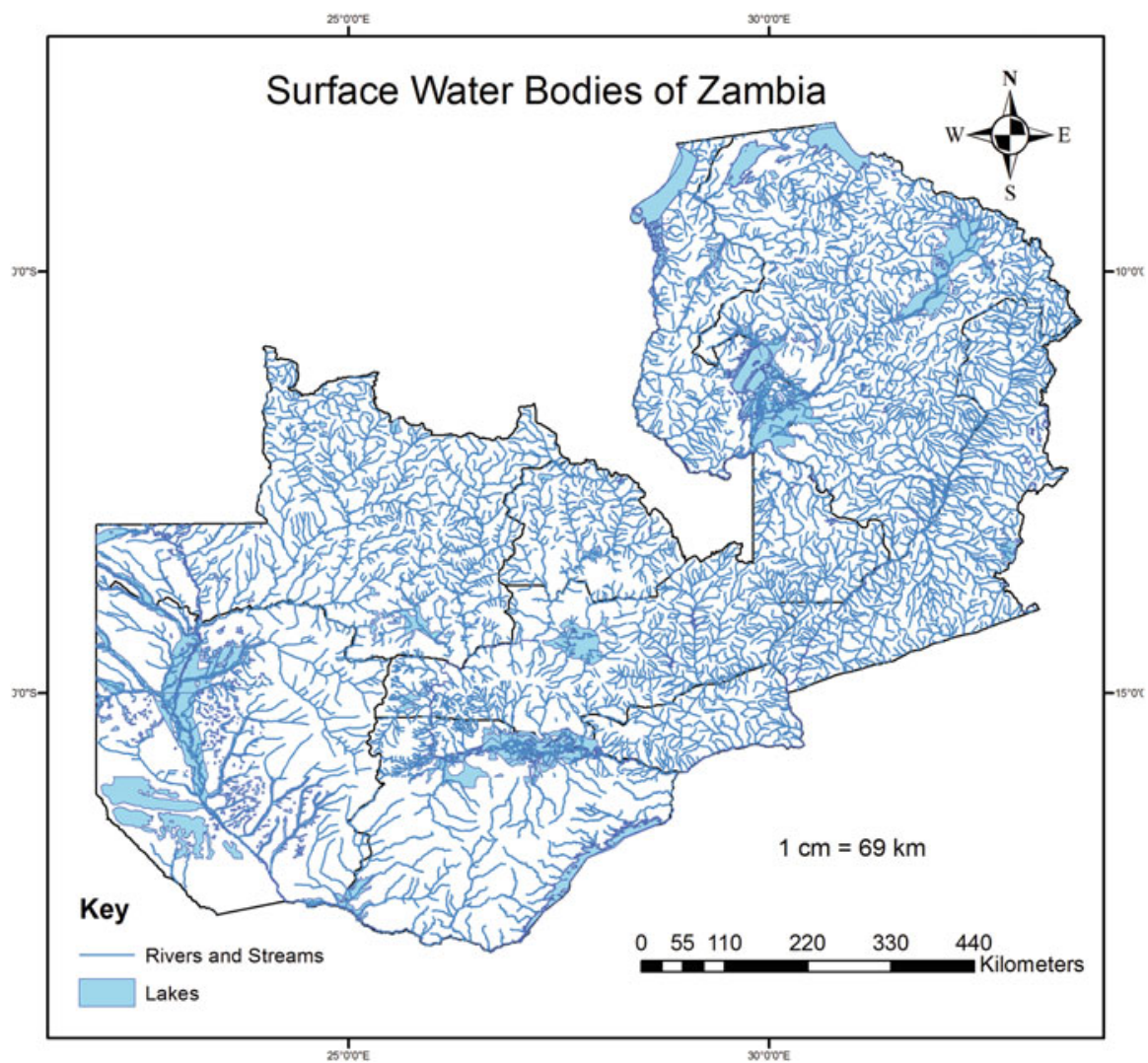

Fig. 11 Surface watercourses and streams

$$
\eta_{p}=\eta_{r} \cdot\left[1-\beta\left(T_{c}-T_{r}\right)\right]
$$

where $\beta$ is a temperature coefficient for module efficiency, $T_{c}$ is a module temperature due to air temperature, and $\mathrm{T}_{\mathrm{r}}$ is STC reference temperature.

Module temperature is related to the average monthly ambient air temperature, Ta, for a local condition has been calculated using Eq. 5 (Didler 2012).

$$
T_{c} ;=T_{a}+\frac{G_{T}}{G_{T . N O C T}}\left(\frac{9.5}{5.7+3.8 V_{W}}\right)\left(T_{c, N O C T}-20\right)\left(1-\eta_{m}\right)
$$

where $\mathrm{G}_{\mathrm{T}}$ is solar irradiance $\left(\mathrm{W} / \mathrm{m}^{2}\right), \mathrm{T}_{\mathrm{a}}$ is ambient air temperature $\left({ }^{\circ} \mathrm{C}\right)$, and $\mathrm{V}_{\mathrm{W}}$ is wind $\operatorname{speed}(\mathrm{m} / \mathrm{s})$ for the location, $\mathrm{T}_{\mathrm{c}, \mathrm{NOCT}}$ is nominal operating cell temperature (Table 3), it depends on type of PV technology, $\eta_{\mathrm{m}}$ is the factor less than 1 and normally neglected and $\mathrm{G}_{\mathrm{T}, \text { NOCT }}$ is $800 \mathrm{~W} / \mathrm{m}^{2}$. 


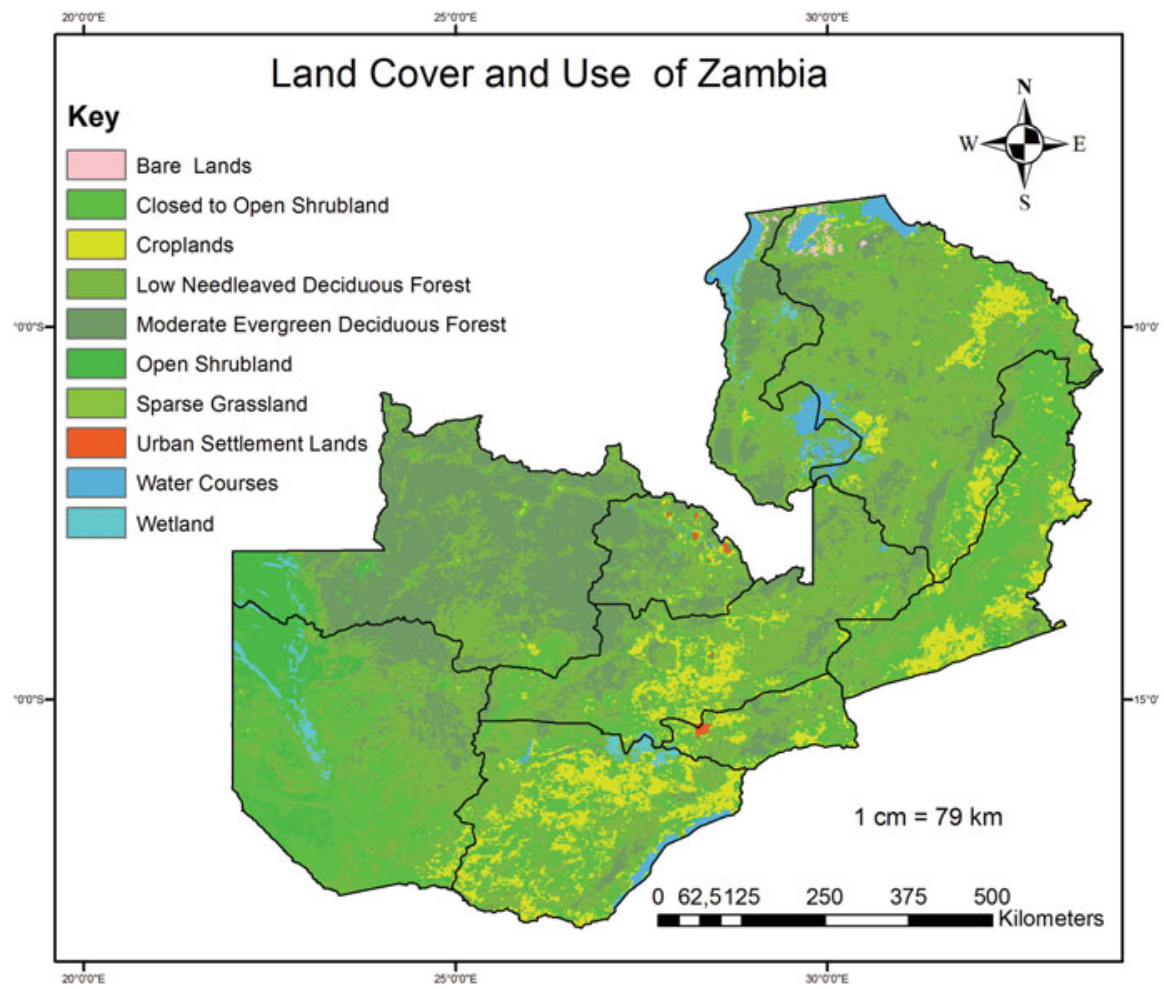

Fig. 12 Land aspects

\section{Performance Ratio Model}

Performance ratio is denoted by PR, this factor is important as it shows the overall effect of losses on the PV array's rated output power due to the PV array temperature, incomplete use of the solar irradiation, and PV system component inefficiencies or failures. It is calculated as (British Standard 1998).

$$
P R=\frac{Y_{F}}{Y_{R}}=\frac{E_{A C}}{G \eta_{S T C}}
$$

where G-standard test condition solar radiance $\left(1 \mathrm{~kW} / \mathrm{m}^{2}\right)$ and $\eta_{\mathrm{STC}}$-array efficiency at standard test condition given as.

$$
\eta_{S T C}=\frac{P_{P V}}{G A_{P V \cdot A}}
$$

where $A_{P V, A^{-}}$-Active array area $\left(\mathrm{m}^{2}\right)$ and $\mathrm{P}_{\mathrm{PV}, \mathrm{A}^{-}}$array rated power $\left(\mathrm{kW}_{\mathrm{P}}\right)$. 
Table 3 Environmental and social consideration for site selection in Zambia (ECZ 1994)

\begin{tabular}{|c|c|c|}
\hline Issues & Considerations & Effect description \\
\hline \multirow[t]{3}{*}{ Ecological } & (a) Biological diversity. & $\begin{array}{l}\text { - Effect on number, diversity, breeding sites, } \\
\text { etc. of flora and fauna } \\
\text { - Effect on the gene pools of domesticated } \\
\text { and wild sustainable yield }\end{array}$ \\
\hline & $\begin{array}{l}\text { (b) Sustainable use } \\
\text { including: }\end{array}$ & $\begin{array}{l}\text { - Effect of soil fertility } \\
\text { - Breeding populations of fish and wildlife } \\
\text { (game) } \\
\text { - Natural regeneration of woodland and } \\
\text { sustainable yield }\end{array}$ \\
\hline & $\begin{array}{l}\text { (c) Ecosystem } \\
\text { maintenance including: }\end{array}$ & $\begin{array}{l}\text { - Effects of proposal on food chains } \\
\text { - Nutrient cycles } \\
\text { - Aquifer recharge, water run-off rates, etc. } \\
\text { - Aerial extent of habitats } \\
\text { - Biogeographical processes }\end{array}$ \\
\hline $\begin{array}{l}\text { Social, economic, } \\
\text { and cultural }\end{array}$ & \multicolumn{2}{|c|}{$\begin{array}{l}\text { - Effects of generation or reduction of employment in the area } \\
\text { - Social cohesion or disruption (resettlement) } \\
\text { - Immigration (including induced development when people are attracted } \\
\text { to a development site because of possible enhanced economic } \\
\text { opportunities) } \\
\text { - Communication-roads opened up, closed, re-routed } \\
\text { - Local economic impacts }\end{array}$} \\
\hline Land scope & \multicolumn{2}{|c|}{$\begin{array}{l}\text { - Views opened up or closed } \\
\text { - Visual impacts (features, removal of vegetation, etc.) } \\
\text { - Compatibility with surrounding areas } \\
\text { - Amenity opened up or closed, e.g., recreation facilities }\end{array}$} \\
\hline Land use & \multicolumn{2}{|c|}{$\begin{array}{l}\text { - Effects on land uses and land potential in the project area and in the } \\
\text { surrounding areas } \\
\text { - Possibility of multiple use }\end{array}$} \\
\hline Water & \multicolumn{2}{|c|}{$\begin{array}{l}\text { - Effects on surface water quality and quantity } \\
\text { - Effects on underground water quality and quantity } \\
\text { - Effect on the flow regime the water course }\end{array}$} \\
\hline Air quality & \multicolumn{2}{|c|}{$\begin{array}{l}\text { - Effects on the quality of the ambient air of the area } \\
\text { - Type and amount of possible emissions (pollutants) }\end{array}$} \\
\hline
\end{tabular}

\section{Capacity Factor Model}

This is a model used to show the amount of energy delivered to the grid by an electric power generation system (Ayompe 2014). It is defined as the ratio of the output actual annual energy generated by PV system to the amount of energy the PV system would generate if it is operated continuously at full rated power for 8,760 hours in a year and it is expressed as (Ayompe 2014; Kynakis 2009; British Standard 1998).

$$
C F .=\frac{E_{A C}}{8760 \times P_{P V}}=\frac{P R \times H_{t}}{8760 \times P_{P V}}
$$

where $\mathrm{CF}$ is capacity factor $(\%), \mathrm{E}_{\mathrm{AC}}$ is Actual annual energy output $(\mathrm{kWh} / \mathrm{year})$, and $\mathrm{P}_{\mathrm{PV}}$ is Full rated $\mathrm{PV}$ power $\left(\mathrm{kW}_{\mathrm{p}}\right)$. 


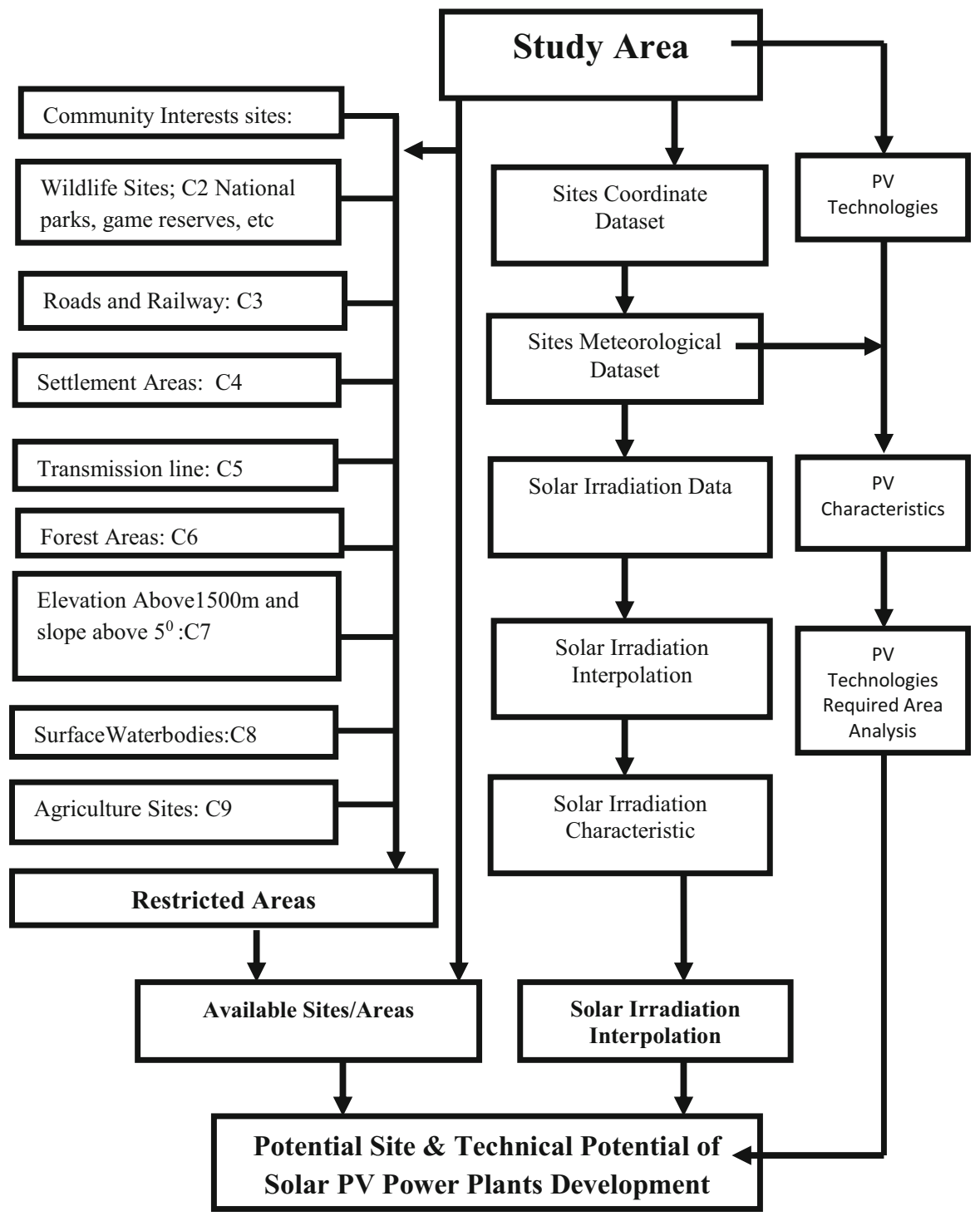

Fig. 13 Analysis Procedure

\section{Solar Energy Potential Model}

\section{Theoretical Solar Energy Potential Model}

Theoretical solar energy potential involves the assessment of the total solar energy that is received at the surface of the study area. This potential involves identifying the study area boundary and the size of the study land area, including total annual 
Table 4 PV technology parameters

\begin{tabular}{l|l|l|l|l|l|l}
\hline \multirow{2}{*}{$\begin{array}{l}\text { PV technology } \\
\text { parameters }\end{array}$} & \multicolumn{5}{l}{ PV technologies } & \multicolumn{2}{l}{} \\
\cline { 2 - 7 } & $\mathrm{mc}-\mathrm{Si}$ & $\mathrm{Pc}-\mathrm{Si}$ & $\mathrm{a}-\mathrm{Si}$ & $\mathrm{CIS}$ & $\mathrm{CdTe}$ & Reference \\
\hline Efficiency $(\%)$ & 23 & 16 & $7-10$ & 12.1 & 11.2 & IRENA 2012 \\
\hline Temp. Coeff. $\beta\left(\% /{ }^{0} \mathrm{C}\right)$ & 0.41 & 0.43 & 0.27 & 0.26 & 0.25 & $\begin{array}{l}\text { Suprava and } \\
\text { Pradip 2015 }\end{array}$ \\
\hline $\begin{array}{l}\text { Active PV area needed } \\
\left(\mathrm{m}^{2} / \mathrm{kW}\right)\end{array}$ & 7 & 8 & 15 & 10 & 11 & IRENA 2012 \\
\hline $\begin{array}{l}\text { Total PV system area } \\
\text { needed }\left(\mathrm{m}^{2} / \mathrm{MW}\right)\end{array}$ & 14,000 & 16,000 & 30,000 & 20,000 & 220,000 & Estimated \\
\hline \begin{tabular}{l} 
NOCT $\left({ }^{\circ} \mathrm{C}\right)$ \\
\hline Max. PV module $(\mathrm{W})$
\end{tabular} & 37 & 45 & 40.3 & 45.6 & 45 & $\begin{array}{l}\text { Suprava and } \\
\text { Pradip 2015 }\end{array}$ \\
\hline BOS losses $(\%)$ & 8 & 8 & 8.13 & 11.33 & 11.33 & $\begin{array}{l}\text { Various } \\
\text { sources }\end{array}$ \\
\hline Dust factor $(\%)$ & 5 & 5 & 5 & 5 & 5 & $\begin{array}{l}\text { Various } \\
\text { sources }\end{array}$ \\
\hline
\end{tabular}

average solar radiation magnitude. The theoretical potential has been calculated using Eq. 9:

$$
E_{T H}=A_{S} \cdot H_{P}
$$

where $E_{T H}$ is theoretical solar energy potential (MWh/year), $A_{s}$ is study area active surface area $\left(\mathrm{km}^{2}\right)$, and $\mathrm{H}_{\mathrm{R}}$ is total annual average solar irradiance $\left(\mathrm{MWh} / \mathrm{km}^{2}\right.$-year).

\section{Geographical Solar Energy Potential Model}

Geographical solar energy potential involves assessing the solar energy that is received on the available and suitable land area of the active surface land area of study area (Lopez 2012). Hence, the process of assessing this potential involved firstly excluding all the protected and restricted areas from the active surface area of the study area under consideration (Yan-wei 2013; Lopez 2012).

Therefore, the remaining surface land area is taken as the most suitable land area of the total study area surface land area for solar energy technologies development. In this study, the geographical solar energy potential has been estimated using Eq. 10 given below:

$$
E_{G}=A_{A O S} \cdot H_{R} .
$$

where $E_{G}$ is geographical solar energy potential $(\mathrm{kWh} / \mathrm{year}), \mathrm{A}_{\mathrm{ADS}}$ is Available Suitable Area $\left(\mathrm{m}^{2}\right)$, and $\mathrm{H}_{\mathrm{R}}$ is total annual average solar radiation $\left(\mathrm{kWh} / \mathrm{m}^{2}\right.$-year). 


\section{Solar PV Technical Power Potential Model}

The process of assessing the feasible solar PV technical potential, that is, the maximum power capacity that can be installed for any country without environmental and social impacts involves firstly by excluding restricted areas and areas not suitable for utility-scale PV systems development within the defined boundaries. Furthermore, considering technical characteristics of solar PV technologies (Table 3) to convert the solar energy to electrical energy, the total solar energy that is received at the surface of the solar PV module and the area required by the PV system and its supporting infrastructures. Hence, the technical solar PV potential has been estimated using Eq. 11 (Yan-wei 2013; Lopez 2012):

$$
P_{T P}=\left(\frac{A_{A D S}}{A_{P V S A}}\right) \cdot=P_{P D} A_{P V}
$$

where $\mathrm{P}_{\mathrm{TP}}$ is Solar PV Power Potential (MW), $\mathrm{A}_{\mathrm{PVSA}}$ is Solar PV system and Supporting Infrastructure Occupied Area per MW $\left(\mathrm{km}^{2} / \mathrm{MW}\right), \mathrm{A}_{\mathrm{ADS}}$ is Available Suitable Area for Study Area $\left(\mathrm{km}^{2}\right), \mathrm{A}_{\mathrm{PV}}$ is total geographical occupied area by PV system and supporting infrastructure $\left(\mathrm{km}^{2}\right)$, and $\mathrm{P}_{\mathrm{PD}}$ is solar power density of the area $\left(\mathrm{MW} / \mathrm{km}^{2}\right)$.

\section{Solar PV Systems Electricity Generation Technical Potential Model}

The total AC electricity generated by the PV system is the sum of the electricity produced by all array in the PV power plant measured at the point where the system fed to utility grid. The total daily $\mathrm{E}_{\mathrm{AC}, \mathrm{DP}}$ and monthly $\mathrm{E}_{\mathrm{AC}, \mathrm{mP}} \mathrm{AC}$ energy generated by plant are expressed as (Ali et al. 2016; Tripathi et al. 2014; Siyasankari and Babu 2015):

$$
\begin{gathered}
E_{A C, D P}=\sum_{t-1}^{24} E_{A C, t} \\
E_{A C, m P}=\sum_{d-1}^{N} E_{A C, D P}
\end{gathered}
$$

where $\mathrm{N}$ is number of days in the month, and $\mathrm{E}_{\mathrm{AC}, \mathrm{t}}$ is energy produced by $\mathrm{PV}$ power plant per hour $(\mathrm{kWh})$.

Utility-scale photovoltaic are large-scale solar PV power plant that can be deployed within the boundaries of the country on an open space land area (Lopez 2012). Several studies have considered that the modules covers the available suitable areas on horizontal; however, the method proposed in this study seeks to consider the active area of PV arrays only and also the supporting infrastructures in the evaluation of technical potential. The process of assessing the extractable electricity generation potential from the sun for any country involves firstly by excluding areas not suitable for utility-scale PV systems within the defined boundaries, and secondly, considering technical characteristics of PV systems to convert the solar energy to electrical 
energy and the area required by the PV system and its supporting infrastructures. In this study the technical solar energy potential was estimated using Eq. 14 (Yan-wei 2013; Lopez 2012):

$$
E_{T}=P_{T P} . C F . T_{T S H}
$$

where $\mathrm{E}_{\mathrm{T}}$ is Solar PV Electricity Generation Potential (MWh/year), $\mathrm{P}_{\mathrm{TP}}$ is the technical power potential (MW), CF is Study Area Capacity factor (\%), and $\mathrm{T}_{\mathrm{TSH}}$ is the hours of the whole year ( 8,760 hours/year).

\section{Potential Site and Electricity Generation Potential}

\section{Solar PV Potential Sites and Mapping}

Figure 14 presents the map of solar PV potential suitable sites evaluated for Zambia, which indicates that the country has large land areas suitable for solar PV power plant development both at district and provincial levels. The aim of this case was focused on mapping the potential sites suitable for PV power plant installation with minimized or no environmental and social impacts. Therefore, all limiting factors considered not suitable for PV systems and those areas likely to have environmental and social issues were eliminated in the analysis using GIS spatial analysis. Hence, the Solar PV Potential Sites atlas shows that the country has the largest suitable site for solar PV power plant development in the Southern Province with Lusaka Province having the least. However, it can be observed that the available suitable areas are distributed throughout the country, hence providing opportunity for wide deployment of the solar PV technologies across the country. In addition, the atlas also shows that regions near to the national power grid contain suitable sites for easy integration of these technologies into the national energy mix and national power grid. The atlas provides essential information for sites close to villages and towns far from the grid offering opportunity for mini off-grid systems. Therefore, the atlas offers vital information for setting targets for electrification of both rural and urban areas of the country.

\section{Available Suitable Land Area}

Table 5 shows the annual average solar irradiation, total surface area and the available suitable areas for each district of Zambia. This reveals significant differences in suitable available areas within the 75 districts and 9 provinces across the country due to the availability of the aforementioned restricting factors considered in the evaluation. It can be observed that the districts in Eastern Province have lowest ratios of suitable area to surface areas in the ranges of 1.57 to $11.61 \%$ mainly due to the availability of restricting factors such as escapement, protected areas (e.g., National Parks, Zones of higher Agriculture Potential), and agriculture activities. 


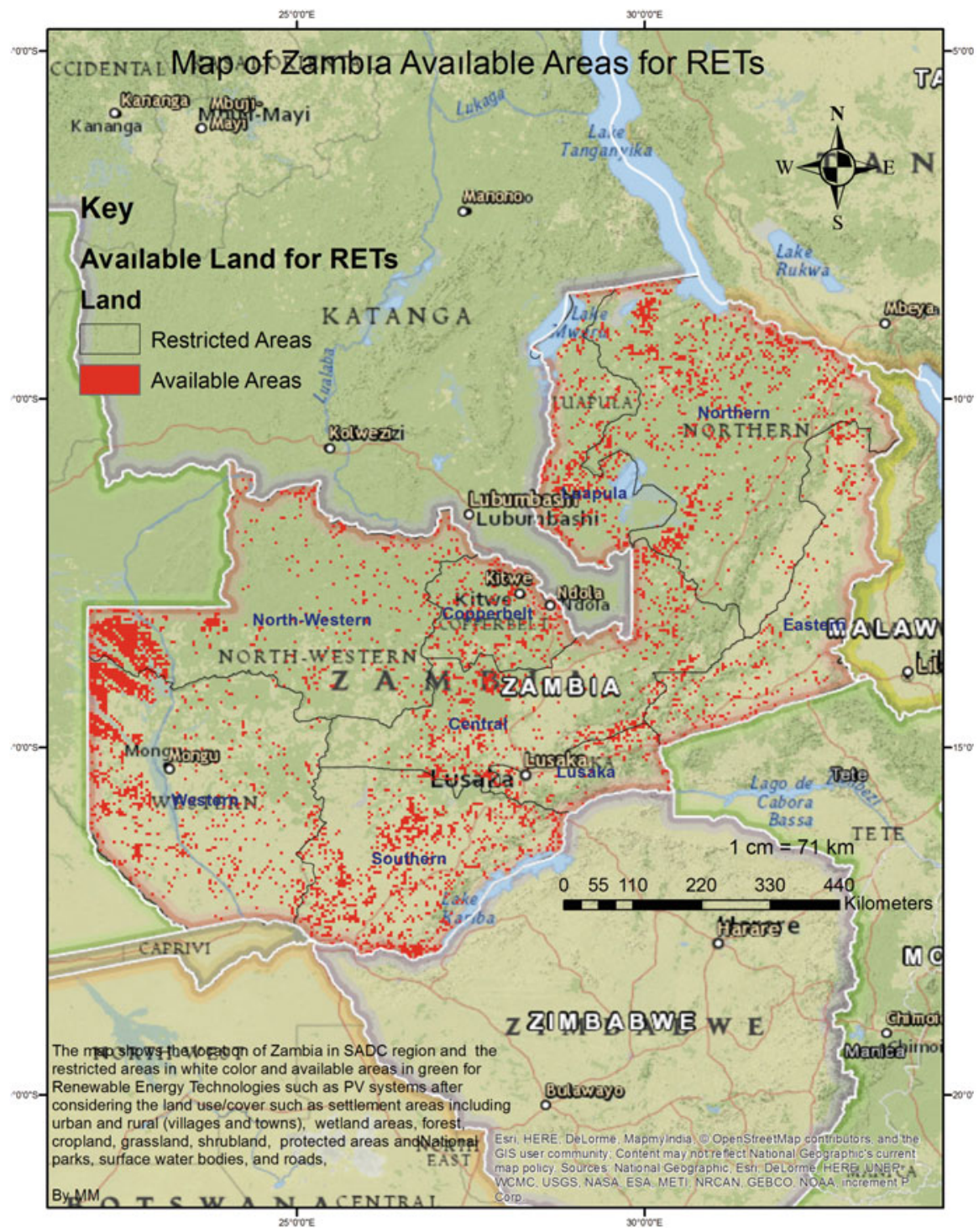

Fig. 14 Potential suitable sites for utility-scale solar PV power plant deployment

The provincial total suitable areas available for utility-scale solar photovoltaic power plants development as shown in Table 6 ranged from $2,151.70 \mathrm{~km}^{2}$ (Lusaka) to $16,593.56 \mathrm{~km}^{2}$ (Southern). As earlier stated, Eastern Province has the lowest annual average solar irradiation and also the overall percent suitable area $(6.61 \%)$ whereas Southern Province has the largest (19.33\%). However, Lusaka Province due to its size and population has the lowest overall suitable area $\left(2,151.70 \mathrm{~km}^{2}\right)$ followed by Copperbelt $\left(4,475.66 \mathrm{~km}^{2}\right)$ and highest being the Southern Province 


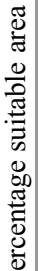

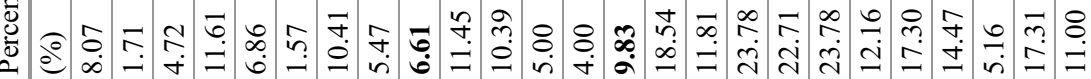
Ðே

$\stackrel{Ð}{\overparen{\leftrightarrows}}$

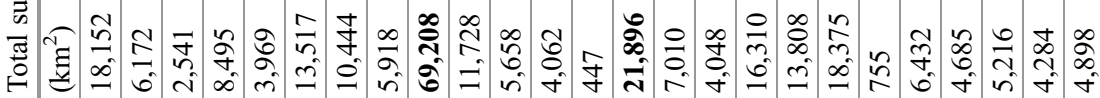

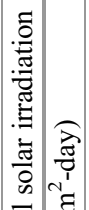

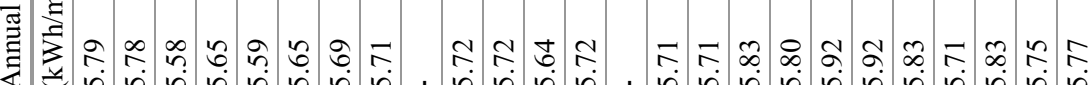

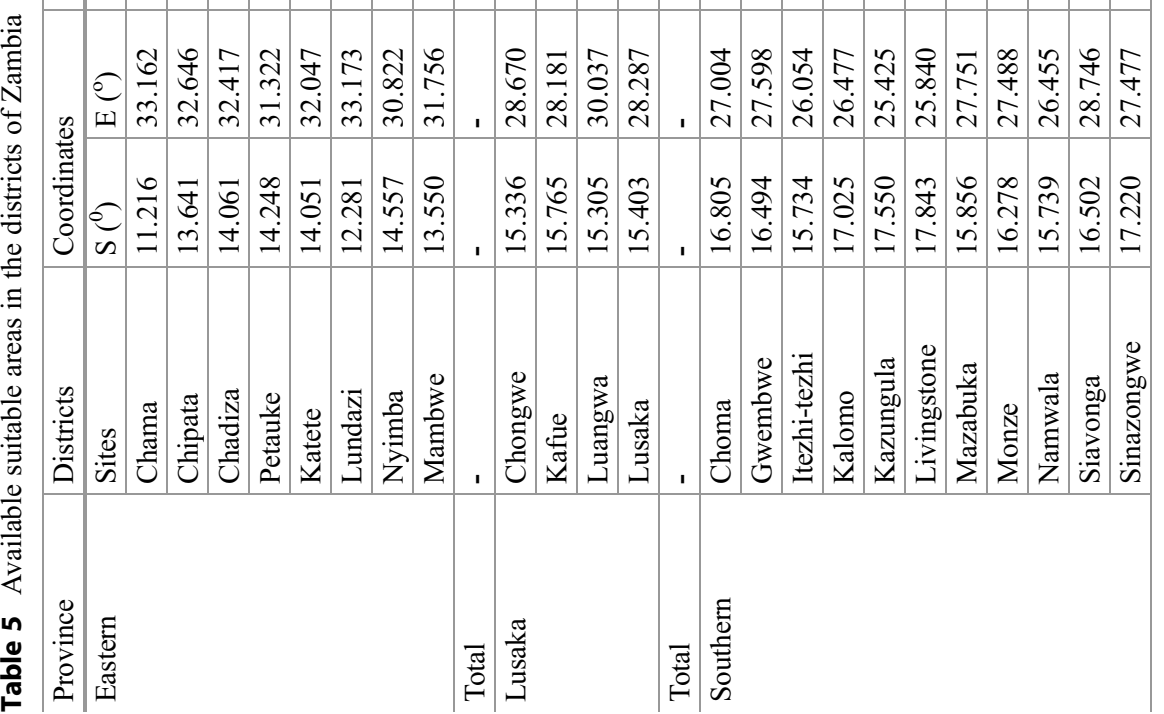




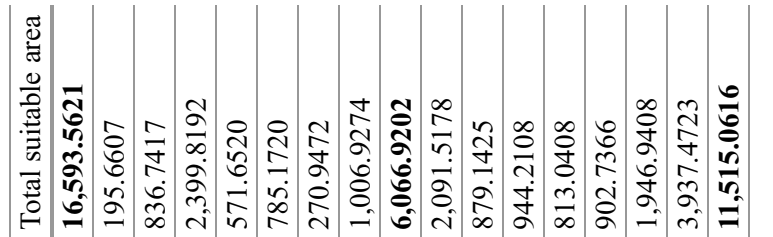

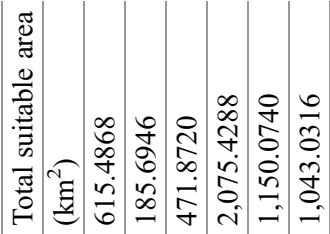

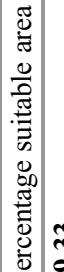

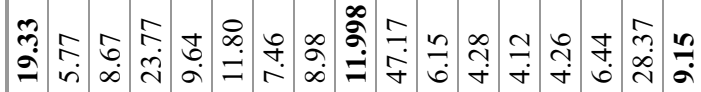

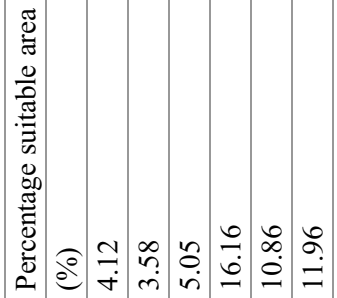

ฐ্

离

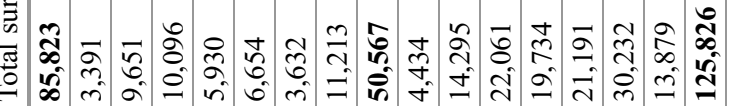

ֻँ

巡

言

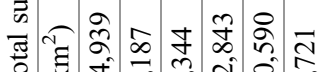
웡 जी ने

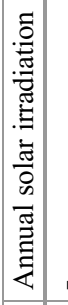

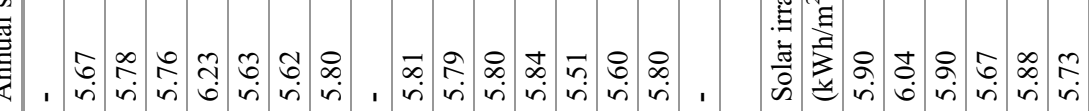

:

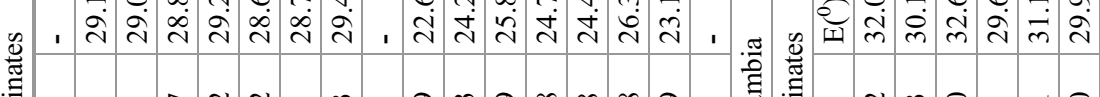

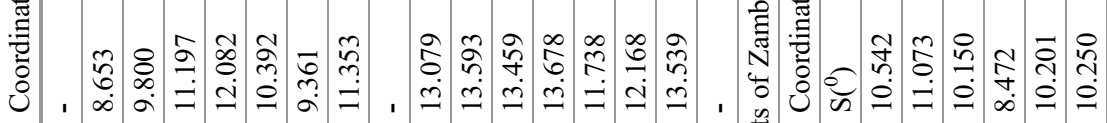
$\begin{array}{llll}0 & 0\end{array}$

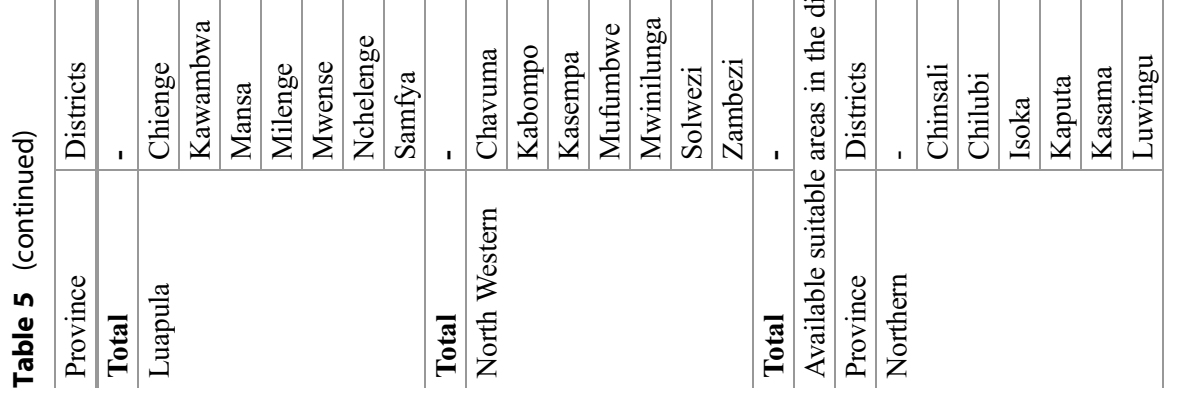




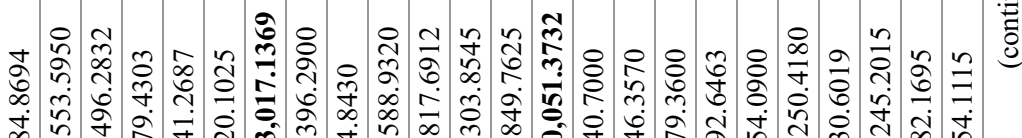

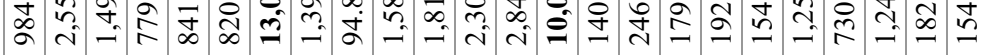

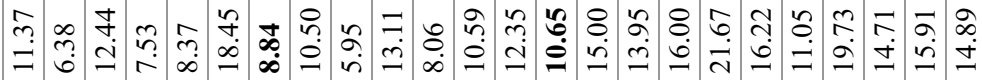

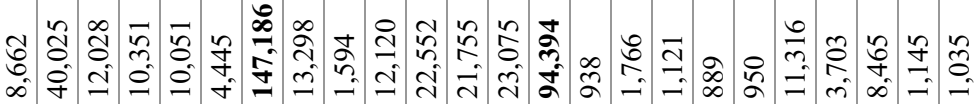

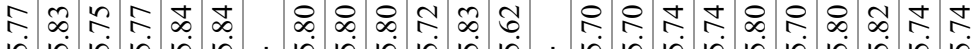

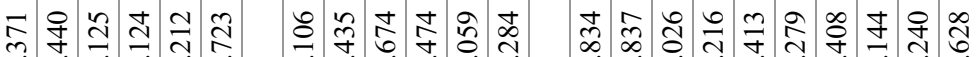

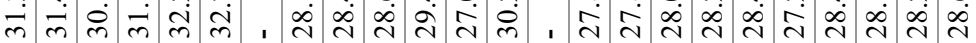

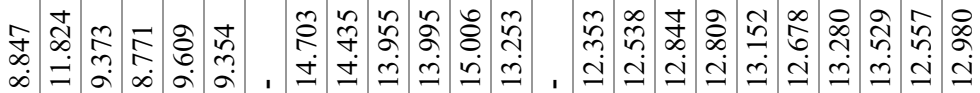

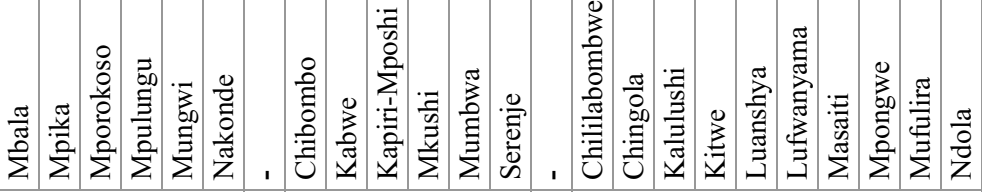

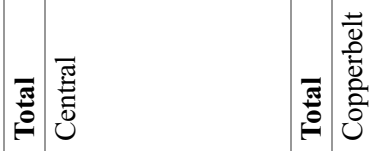




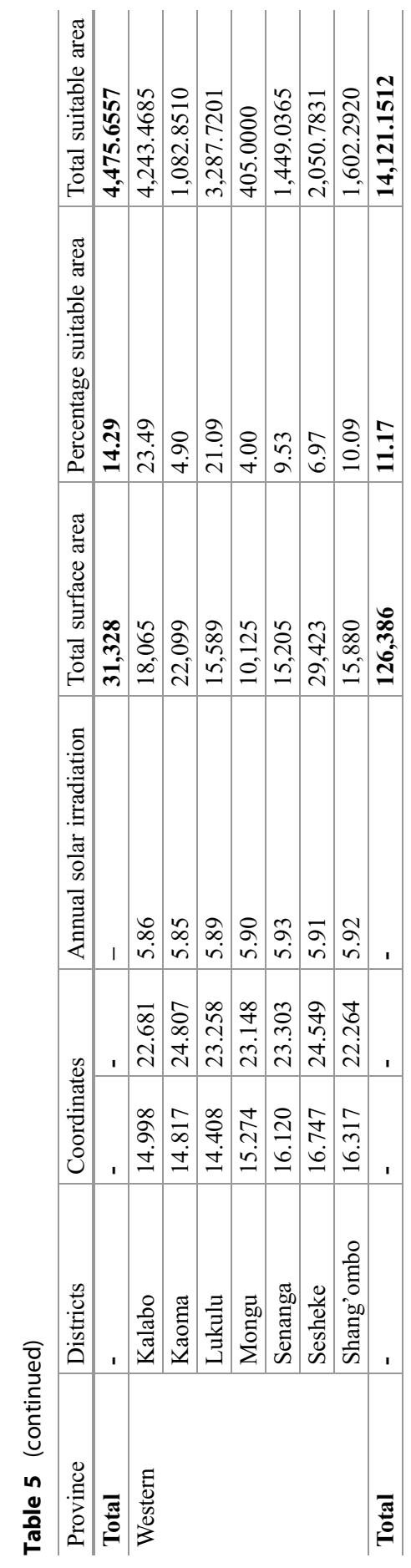


Table 6 Provincial total suitable areas for utility-scale solar photovoltaic power plants

\begin{tabular}{l|l|l|l|l}
\hline \multirow{2}{*}{ Province } & Annual solar irradiation & Total area & Suitable area & Percent suitable area \\
\cline { 2 - 5 } & $\left(\mathrm{kWh} / \mathrm{m}^{2}\right.$-day) & $\left(\mathrm{km}^{2}\right)$ & $\left(\mathrm{km}^{2}\right)$ & $(\%)$ \\
\hline Lusaka & 5.70 & 21,896 & $2,151.7022$ & 9.82 \\
\hline Luapula & 5.78 & 50,567 & $6,066.9202$ & 12.00 \\
\hline Central & 5.76 & 94,394 & $10,051.3732$ & 10.65 \\
\hline Copperbelt & 5.75 & 31,328 & $4,475.6557$ & 14.29 \\
\hline Northern & 5.83 & 147,186 & $13,017.1369$ & 8.84 \\
\hline N/Western & 5.74 & 125,826 & $11,515.0616$ & 9.15 \\
\hline Western & 5.89 & 126,386 & $14,121.1512$ & 11.17 \\
\hline Southern & 5.80 & 85,823 & $16,593.5621$ & 19.33 \\
\hline Eastern & 5.68 & 69,208 & $4,572.0376$ & 6.61 \\
\hline Zambia & $\mathbf{5 . 7 8}$ & $\mathbf{7 5 2 , 6 1 4}$ & $\mathbf{8 2 , 5 6 4 . 6 0 0 7}$ & $\mathbf{1 0 . 9 7}$ \\
\hline
\end{tabular}

$\left(16,593.56 \mathrm{~km}^{2}\right)$ (Fig. 15a, b). In short, comparing only available suitable areas where installation of PV system is suitable, Southern province has about 7.71 times more suitable area than Lusaka Province. However, there are large differences in surface area size between the two provinces, with Lusaka having 3.92 times less surface area than Southern Province. The country has approximately $10.97 \%$ equivalent to $82,564.60 \mathrm{~km}^{2}$ of the total suitable surface land area for development of utility-scale solar PV power plant (Table 6).

\section{Electrical Power and Electricity Generation Potential}

Table 7 shows district solar energy theoretical and geographical energy potential. Since these potentials depend on the solar irradiation and available surface area and available geographical suitable areas. Hence areas with larger surfaces and receiving the higher solar irradiation such as Northern, Western, and North-Western have the highest overall theoretical potential whereas areas with larger suitable areas such as Southern, Western, Northern, North-Western, and Central Provinces have higher geographical solar energy potential (Table 8 and Fig. 16).

The district-based solar PV technical power potential by technology (Table 9) shows that crystalline silicon based solar PV technologies possess large potential due to less land requirements for installation, with monocrystalline-silicon technology having the largest technical power potential of $5,897.46 \mathrm{GW}$ whereas amorphoussilicon having the lowest potential of 2,752.16 GW due to huge land requirements. The variation in power potential per district is highly depended on the available suitable areas in each district which is as a result of local geographical and terrain features.

The provincial solar PV technical power potential per technology (Table 10 and Fig. 17) shows that Southern Province, followed by Western have the highest potential and Lusaka Province being the lowest. Figure 18 shows the comparison 

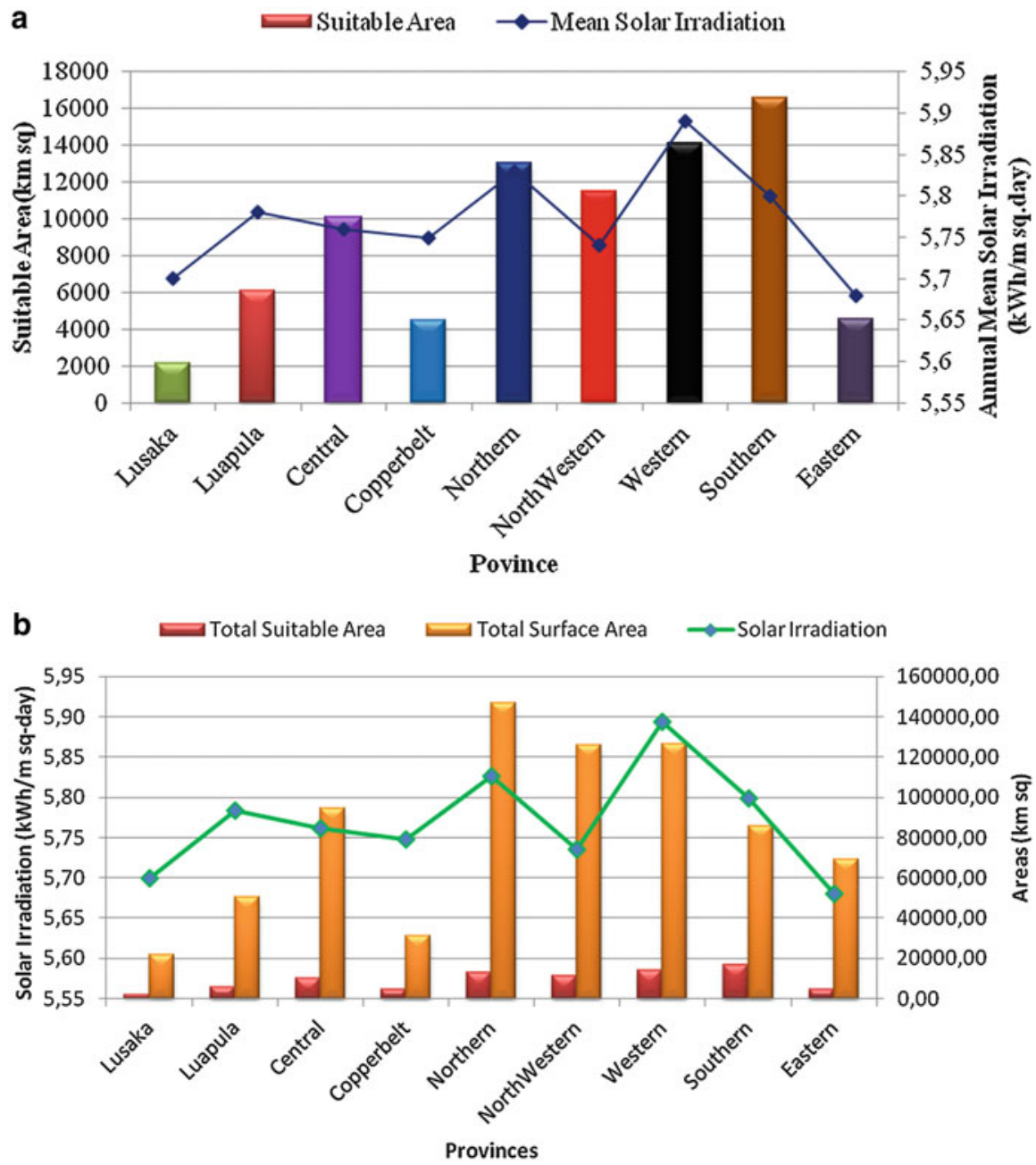

Fig. 15 (a) Provincial total suitable areas for utility-scale solar photovoltaic power plants. (b) Comparison of provincial total surface areas and suitable areas for utility-scale solar photovoltaic power plants

of solar PV technologies peak power potential for Zambia, with monocrystalline silicon having the largest whereas amorphous silicon having the lowest potential.

In absolute numbers, the highest electricity generation can be generated in the Southern, Western, Northern, North-Western, and Central Provinces due to large available suitable land areas for utility-scale solar PV system development (Table 12 and Fig. 19). Table 11 illustrates the district solar PV technical electricity generation potential by technology. Just like technical power potential it can be observed that districts with large suitable areas have the largest electricity generation potential. 


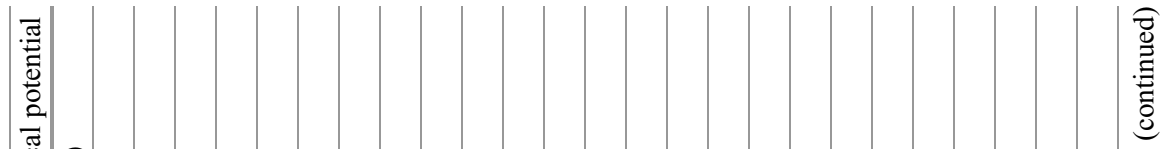

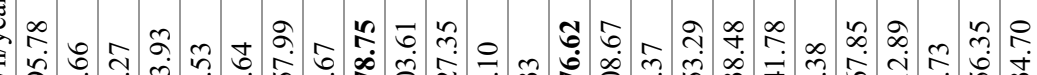

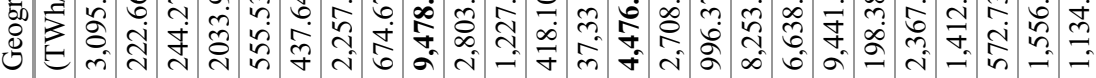

:

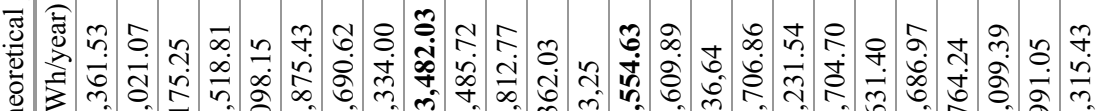

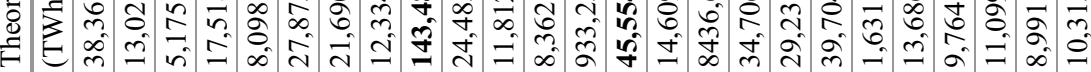

$\overparen{Ð}$

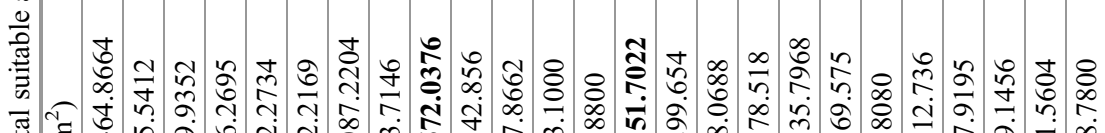

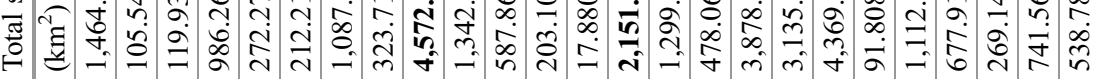

Ð

每

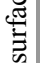

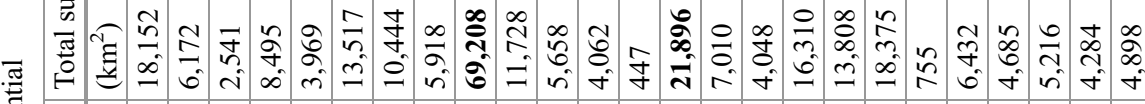

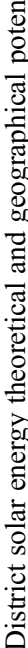

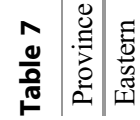

要营

氶 


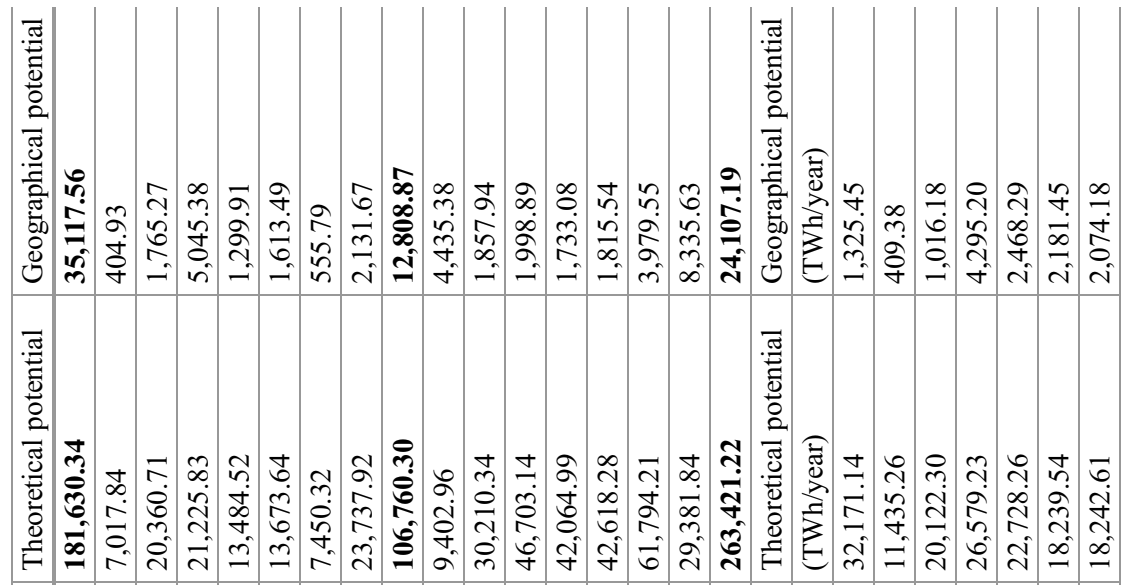
宽 离

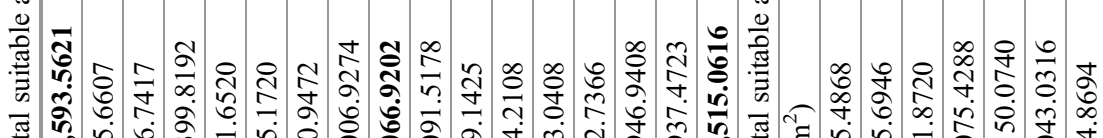

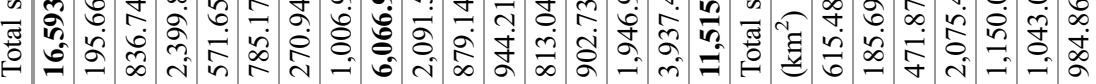
离

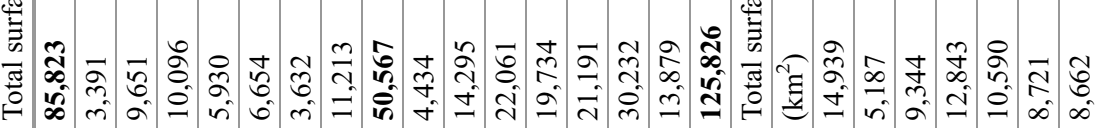
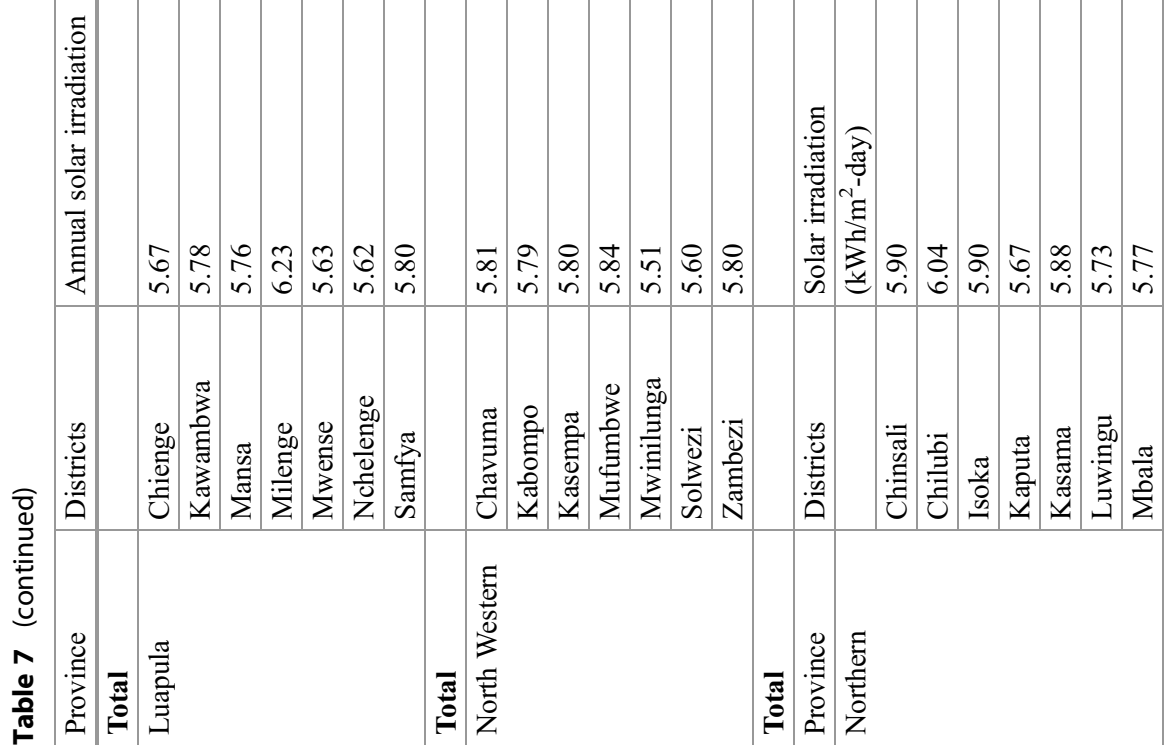


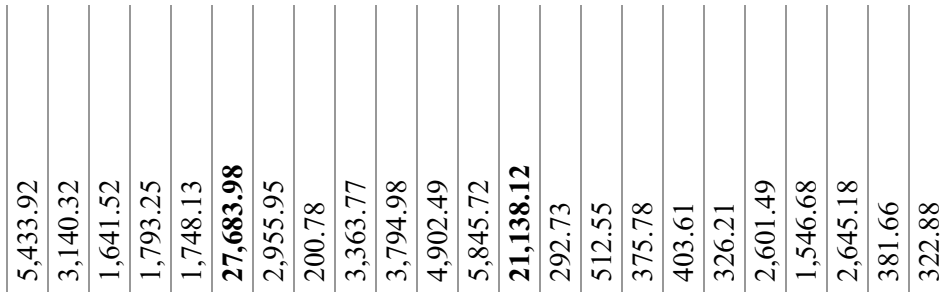

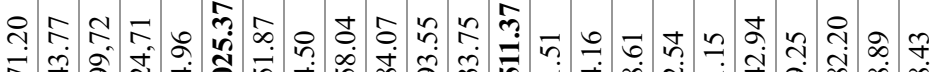

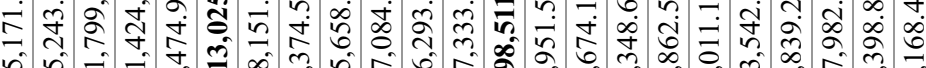

की

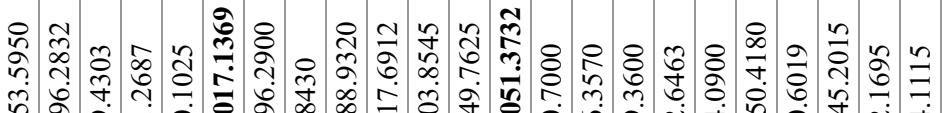

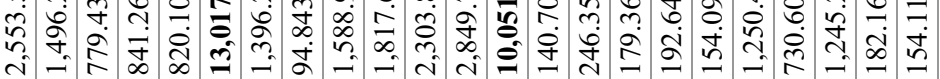

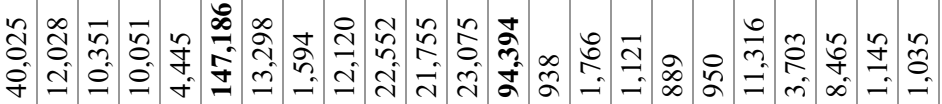

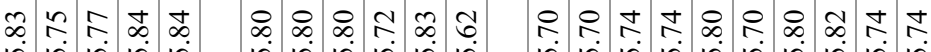

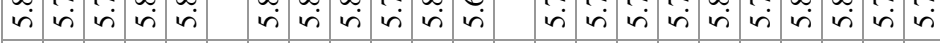

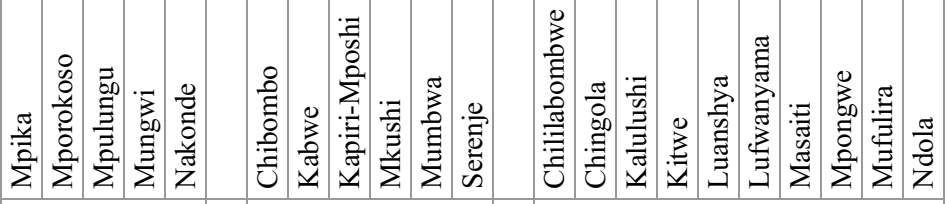

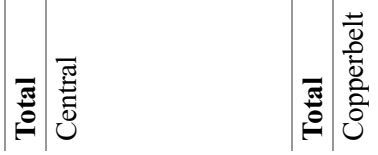




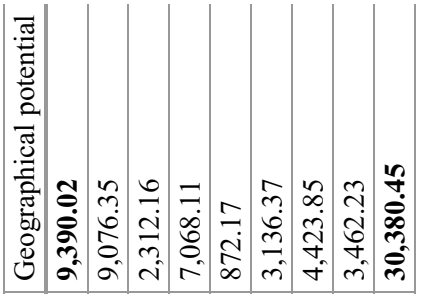

.

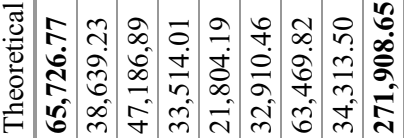

ฮึँ

余

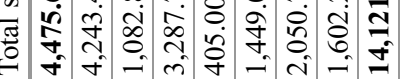

Ð

芯

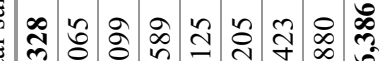

ตั0

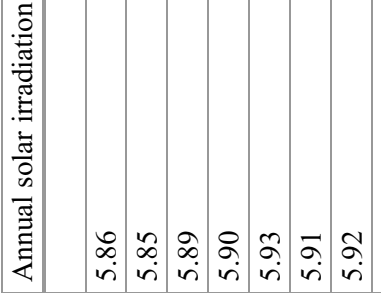

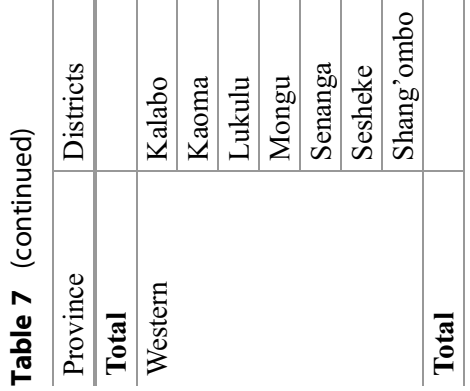


Table 8 Provincial solar energy theoretical and geographical potential

\begin{tabular}{l|l|l|l|l|l}
\hline Province & $\begin{array}{l}\text { Annual } \\
\text { average solar } \\
\text { irradiation }\end{array}$ & $\begin{array}{l}\text { Total } \\
\text { surface } \\
\text { area }\end{array}$ & $\begin{array}{l}\text { Total } \\
\text { suitable } \\
\text { area }\end{array}$ & $\begin{array}{l}\text { Theoretical } \\
\text { energy } \\
\text { potential }\end{array}$ & $\begin{array}{l}\text { Geographical } \\
\text { energy } \\
\text { potential }\end{array}$ \\
\hline Lusaka & $\left(\mathrm{kWh} / \mathrm{m}^{2}\right.$-day) & $\left(\mathrm{km}^{2}\right)$ & $\left(\mathrm{km}^{2}\right)$ & $(\mathrm{TWh} /$ year $)$ & $(\mathrm{TWh} /$ year $)$ \\
\hline Luapula & 5.70 & $21,896.00$ & $2,151.70$ & $45,554.63$ & $4,476.62$ \\
\hline Central & 5.76 & $50,567.00$ & $6,066.92$ & $106,760.30$ & $12,808.87$ \\
\hline Copperbelt & 5.75 & $94,394.00$ & $10,051.37$ & $198,511.37$ & $21,138.12$ \\
\hline Northern & 5.83 & $31,328.00$ & $4,475.66$ & $65,726.77$ & $9,390.02$ \\
\hline Northwestern & 5.74 & $147,186.00$ & $13,017.14$ & $313,025.37$ & $27,683.98$ \\
\hline Western & 5.89 & $125,826.00$ & $11,515.06$ & $263,421.22$ & $24,107.19$ \\
\hline Southern & 5.80 & $126,386.00$ & $14,121.15$ & $271,908.65$ & $30,380.45$ \\
\hline Eastern & 5.68 & $85,823.00$ & $16,593.56$ & $181,630.34$ & $35,117.56$ \\
\hline Zambia & 5.77 & $69,208.00$ & $45,72,0.38$ & $143,482.03$ & $9,478.75$ \\
\hline
\end{tabular}

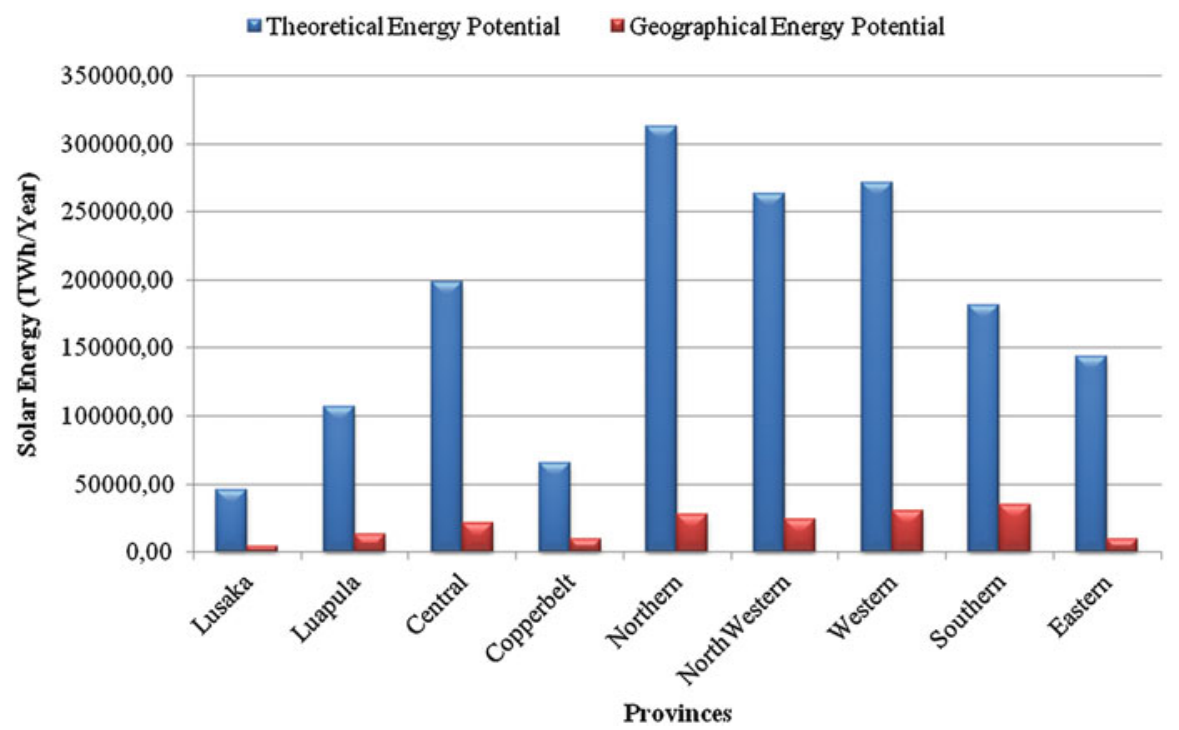

Fig. 16 Provincial solar energy theoretical and geographical potential

Table 12 and Fig.19 show that Southern Province, followed by Western Province have the highest potential while Lusaka province has the lowest potential for electricity generation from solar PV based technologies due to aforementioned issues. Figure 20 shows a comparison of the provincial theoretical and geographical solar energy potential and the technical solar electricity potential. It is worth noting that due to technical characteristic of the solar cell technologies and land requirements the technical solar electricity generation potential is lower as compared to the solar energy received on these potential sites. Hence, this presents the need to select 
Table 9 District solar PV technical power potential by technology

\begin{tabular}{|c|c|c|c|c|c|c|}
\hline \multirow[b]{2}{*}{ Province } & \multirow[b]{2}{*}{ Districts } & \multicolumn{5}{|c|}{ Technical power potential (GW) } \\
\hline & & $\mathrm{mc}-\mathrm{Si}$ & $\mathrm{pc}-\mathrm{Si}$ & $\mathrm{a}-\mathrm{Si}$ & CIS & CdTe \\
\hline \multirow[t]{8}{*}{ Eastern } & Chama & 104.63 & 91.55 & 48.83 & 73.24 & 66.58 \\
\hline & Chipata & 7.54 & 6.60 & 3.52 & 5.28 & 4.80 \\
\hline & Chadiza & 8.57 & 7.50 & 4.00 & 6.00 & 5.45 \\
\hline & Petauke & 70.45 & 61.64 & 32.88 & 49.31 & 44.83 \\
\hline & Katete & 19.45 & 17.02 & 9.08 & 13.61 & 12.38 \\
\hline & Lundazi & 15.16 & 13.26 & 7.07 & 10.61 & 9.65 \\
\hline & Nyimba & 77.66 & 67.95 & 36.24 & 54.36 & 49.42 \\
\hline & Mambwe & 23.12 & 20.23 & 10.79 & 16.19 & 14.71 \\
\hline Total & - & 326.57 & 285.75 & 152.40 & 228.60 & 207.82 \\
\hline \multirow{4}{*}{ Lusaka } & Chongwe & 95.92 & 83.93 & 44.76 & 67.14 & 61.04 \\
\hline & Kafue & 41.99 & 36.74 & 19.60 & 29.39 & 26.72 \\
\hline & Luangwa & 14.51 & 12.69 & 6.77 & 10.16 & 9.23 \\
\hline & Lusaka & 1.28 & 1.12 & 0.60 & 0.89 & 0.81 \\
\hline Total & - & 153.69 & 134.48 & 71.72 & 107.59 & 97.80 \\
\hline \multirow[t]{11}{*}{ Southern } & Choma & 92.83 & 81.23 & 43.32 & 64.98 & 59.08 \\
\hline & Gwembwe & 34.15 & 29.88 & 15.94 & 23.90 & 21.73 \\
\hline & Itezhi-tezhi & 277.04 & 242.41 & 129.28 & 193.93 & 176.30 \\
\hline & Kalomo & 223.99 & 195.99 & 104.53 & 156.79 & 142.54 \\
\hline & Kazungula & 312.11 & 273.10 & 145.65 & 218.48 & 198.62 \\
\hline & Livingstone & 6.56 & 5.74 & 3.06 & 4.59 & 4.17 \\
\hline & Mazabuka & 79.48 & 69.55 & 37.09 & 55.64 & 50.58 \\
\hline & Monze & 48.42 & 42.37 & 22.60 & 33.90 & 30.81 \\
\hline & Namwala & 19.22 & 16.82 & 8.97 & 13.46 & 12.23 \\
\hline & Siavonga & 52.97 & 46.35 & 24.72 & 37.08 & 33.71 \\
\hline & Sinazongwe & 38.48 & 33.67 & 17.96 & 26.94 & 24.49 \\
\hline Total & - & $1,185.25$ & $1,037.10$ & 553.12 & 829.68 & 754.25 \\
\hline \multirow{7}{*}{ Luapula } & Chienge & 13.98 & 12.23 & 6.52 & 9.78 & 8.89 \\
\hline & Kawambwa & 59.77 & 52.30 & 27.89 & 41.84 & 38.03 \\
\hline & Mansa & 171.42 & 149.99 & 79.99 & 119.99 & 109.08 \\
\hline & Milenge & 40.83 & 35.73 & 19.06 & 28.58 & 25.98 \\
\hline & Mwense & 56.08 & 49.07 & 26.17 & 39.26 & 35.69 \\
\hline & Nchelenge & 19.35 & 16.93 & 9.03 & 13.55 & 12.32 \\
\hline & Samfya & 71.92 & 62.93 & 33.56 & 50.35 & 45.77 \\
\hline Total & - & 433.35 & 379.18 & 202.23 & 303.35 & 275.77 \\
\hline \multirow[t]{7}{*}{ North Western } & Chavuma & 149.39 & 130.72 & 69.72 & 104.58 & 95.07 \\
\hline & Kabompo & 62.80 & 54.95 & 29.30 & 43.96 & 39.96 \\
\hline & Kasempa & 67.44 & 59.01 & 31.47 & 47.21 & 42.92 \\
\hline & Mufumbwe & 58.07 & 50.82 & 27.10 & 40.65 & 36.96 \\
\hline & Mwinilunga & 64.48 & 56.42 & 30.09 & 45.14 & 41.03 \\
\hline & Solwezi & 139.07 & 121.68 & 64.90 & 97.35 & 88.50 \\
\hline & Zambezi & 281.25 & 246.09 & 131.25 & 196.87 & 178.98 \\
\hline Total & - & 822.50 & 719.69 & 383.84 & 575.75 & 523.41 \\
\hline
\end{tabular}


Table 9 (continued)

\begin{tabular}{|c|c|c|c|c|c|c|}
\hline \multirow[b]{2}{*}{ Province } & \multirow[b]{2}{*}{ Districts } & \multicolumn{5}{|c|}{ Technical power potential (GW) } \\
\hline & & $\mathrm{mc}-\mathrm{Si}$ & pc-Si & $\mathrm{a}-\mathrm{Si}$ & CIS & CdTe \\
\hline \multirow[t]{2}{*}{ Province } & Districts & \multicolumn{5}{|c|}{ Technical power potential (GW) } \\
\hline & & $\mathrm{Mc}-\mathrm{Si}$ & Pc-Si & a-Si & CIS & CdTe \\
\hline \multirow[t]{12}{*}{ Northern } & Chinsali & 43.96 & 38.47 & 20.52 & 30.77 & 27.98 \\
\hline & Chilubi & 13.26 & 11.61 & 6.19 & 9.28 & 8.44 \\
\hline & Isoka & 33.71 & 29.49 & 15.73 & 23.59 & 21.45 \\
\hline & Kaputa & 148.24 & 129.71 & 69.18 & 103.77 & 94.34 \\
\hline & Kasama & 82.15 & 71.88 & 38.34 & 57.50 & 52.28 \\
\hline & Luwingu & 74.50 & 65.19 & 34.77 & 52.15 & 47.41 \\
\hline & Mbala & 70.35 & 61.55 & 32.83 & 49.24 & 44.77 \\
\hline & Mpika & 182.40 & 159.60 & 85.12 & 127.68 & 116.07 \\
\hline & Mporokoso & 106.88 & 93.52 & 49.88 & 74.81 & 68.01 \\
\hline & Mpulungu & 55.67 & 48.71 & 25.98 & 38.97 & 35.43 \\
\hline & Mungwi & 60.09 & 52.58 & 28.04 & 42.06 & 38.24 \\
\hline & Nakonde & 58.58 & 51.26 & 27.34 & 41.01 & 37.28 \\
\hline Total & - & 929.80 & 813.57 & 433.90 & 650.86 & 591.69 \\
\hline \multirow[t]{6}{*}{ Central } & Chibombo & 99.74 & 87.27 & 46.54 & 69.81 & 63.47 \\
\hline & Kabwe & 6.77 & 5.93 & 3.16 & 4.74 & 4.31 \\
\hline & Kapiri-Mposhi & 113.50 & 99.31 & 52.96 & 79.45 & 72.22 \\
\hline & Mkushi & 129.84 & 113.61 & 60.59 & 90.88 & 82.62 \\
\hline & Mumbwa & 164.56 & 143.99 & 76.80 & 115.19 & 104.72 \\
\hline & Serenje & 203.55 & 178.11 & 94.99 & 142.49 & 129.53 \\
\hline Total & - & 717.96 & 628.21 & 335.05 & 502.57 & 456.88 \\
\hline \multirow[t]{10}{*}{ Copperbelt } & Chililabombwe & 10.05 & 8.79 & 4.69 & 7.04 & 6.40 \\
\hline & Chingola & 17.60 & 15.40 & 8.21 & 12.32 & 11.20 \\
\hline & Kalulushi & 12.81 & 11.21 & 5.98 & 8.97 & 8.15 \\
\hline & Kitwe & 13.76 & 12.04 & 6.42 & 9.63 & 8.76 \\
\hline & Luanshya & 11.01 & 9.63 & 5.14 & 7.70 & 7.00 \\
\hline & Lufwanyama & 89.32 & 78.15 & 41.68 & 62.52 & 56.84 \\
\hline & Masaiti & 52.19 & 45.66 & 24.35 & 36.53 & 33.21 \\
\hline & Mpongwe & 88.94 & 77.83 & 41.51 & 62.26 & 56.60 \\
\hline & Mufulira & 13.01 & 11.39 & 6.07 & 9.11 & 8.28 \\
\hline & Ndola & 11.01 & 9.63 & 5.14 & 7.71 & 7.01 \\
\hline Total & - & 319.69 & 279.73 & 149.19 & 223.78 & 203.44 \\
\hline \multirow{7}{*}{ Western } & Kalabo & 303.10 & 265.22 & 141.45 & 212.17 & 192.88 \\
\hline & Kaoma & 77.35 & 67.68 & 36.10 & 54.14 & 49.22 \\
\hline & Lukulu & 234.84 & 205.48 & 109.59 & 164.39 & 149.44 \\
\hline & Mongu & 28.93 & 25.31 & 13.50 & 20.25 & 18.41 \\
\hline & Senanga & 103.50 & 90.56 & 48.30 & 72.45 & 65.87 \\
\hline & Sesheke & 146.48 & 128.17 & 68.36 & 102.54 & 93.22 \\
\hline & Shang'ombo & 114.45 & 100.14 & 53.41 & 80.11 & 72.83 \\
\hline Total & - & $1,008.65$ & 882.57 & 470.71 & 706.06 & 641.87 \\
\hline
\end{tabular}


Table 10 Provincial solar PV technical power potential per technology

\begin{tabular}{l|c|c|c|c|r}
\hline \multirow{2}{*}{ Province } & \multicolumn{4}{l}{ Technical Power Potential $(\mathrm{GW})$} & \multicolumn{1}{l}{} \\
\cline { 2 - 6 } & mc-Si & pc-Si & a-Si & \multicolumn{1}{l}{ CIS } & CdTe \\
\hline Lusaka & 153.69 & 134.48 & 71.72 & 107.59 & 97.80 \\
\hline Luapula & 433.35 & 379.18 & 202.23 & 303.35 & 275.77 \\
\hline Central & 717.96 & 628.21 & 335.05 & 502.57 & 456.88 \\
\hline Copperbelt & 319.69 & 279.73 & 149.19 & 223.78 & 203.44 \\
\hline Northern & 929.80 & 813.57 & 433.90 & 650.86 & 591.69 \\
\hline North-Western & 822.50 & 719.69 & 383.84 & 575.75 & 523.41 \\
\hline Western & $1,008.65$ & 882.57 & 470.71 & 706.06 & 641.87 \\
\hline Southern & $1,185.25$ & $1,037.10$ & 553.12 & 829.68 & 754.25 \\
\hline Eastern & 326.57 & 285.75 & 152.40 & 228.60 & 207.82 \\
\hline Zambia & $\mathbf{5 , 8 9 7 . 4 6}$ & $\mathbf{5 , 1 6 0 . 2 8}$ & $\mathbf{2 , 7 5 2 . 1 6}$ & $\mathbf{4 , 1 2 8 . 2 4}$ & $\mathbf{3 , 7 5 2 . 9 3}$ \\
\hline
\end{tabular}

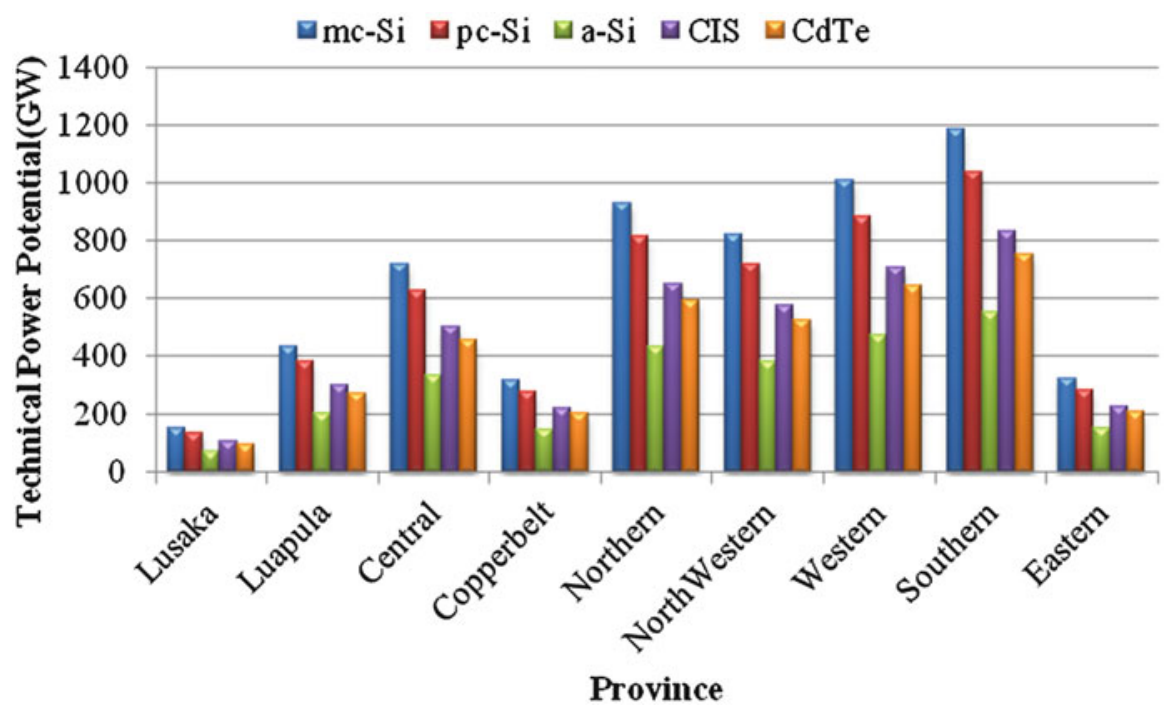

Fig. 17 Provincial solar PV technical power potential per technology

suitable solar cell technology for application in the solar energy harvesting systems for optimal solar energy utilization.

Figure 21 shows the comparison of solar PV technologies for electricity generation potential for Zambia considering the available suitable areas and the technology characteristics. It is observed that monocrystalline provides the highest electricity generation potential followed by polycrystalline and least amorphous. This is mainly due to the differences in amount of land area requirements for the same peak power and the ability of the technology to convert the solar energy into electrical energy (efficiency). 


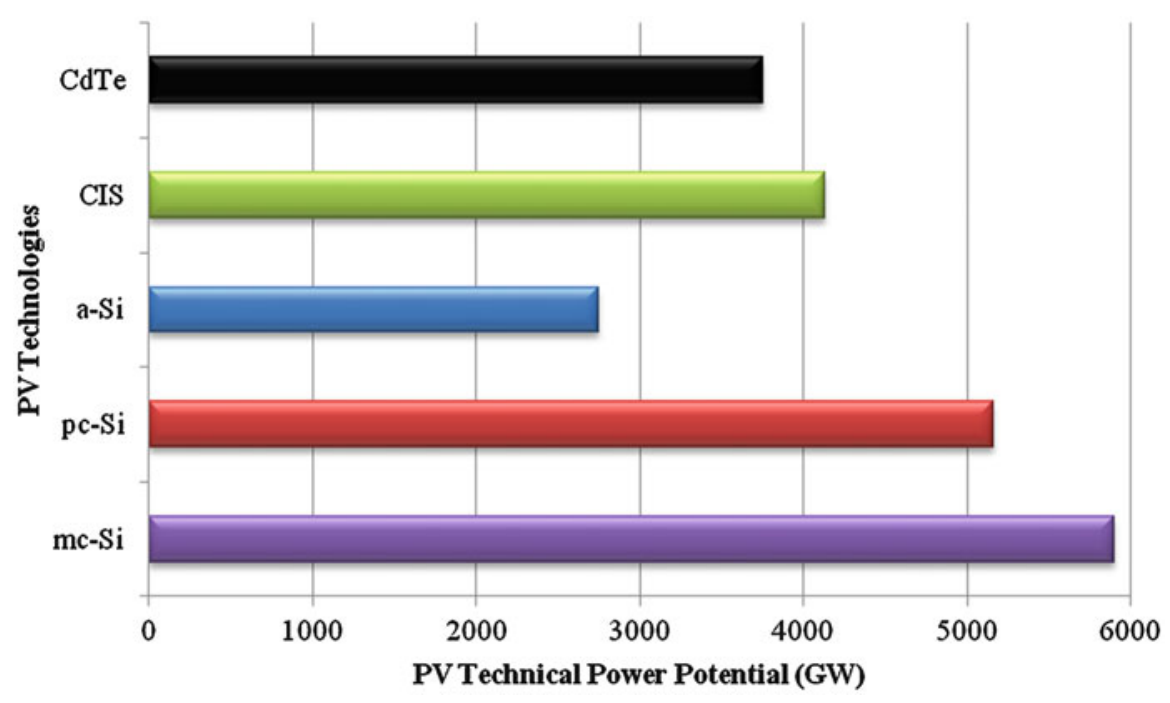

Fig. 18 Comparison of solar PV technical power potential per technology of Zambia

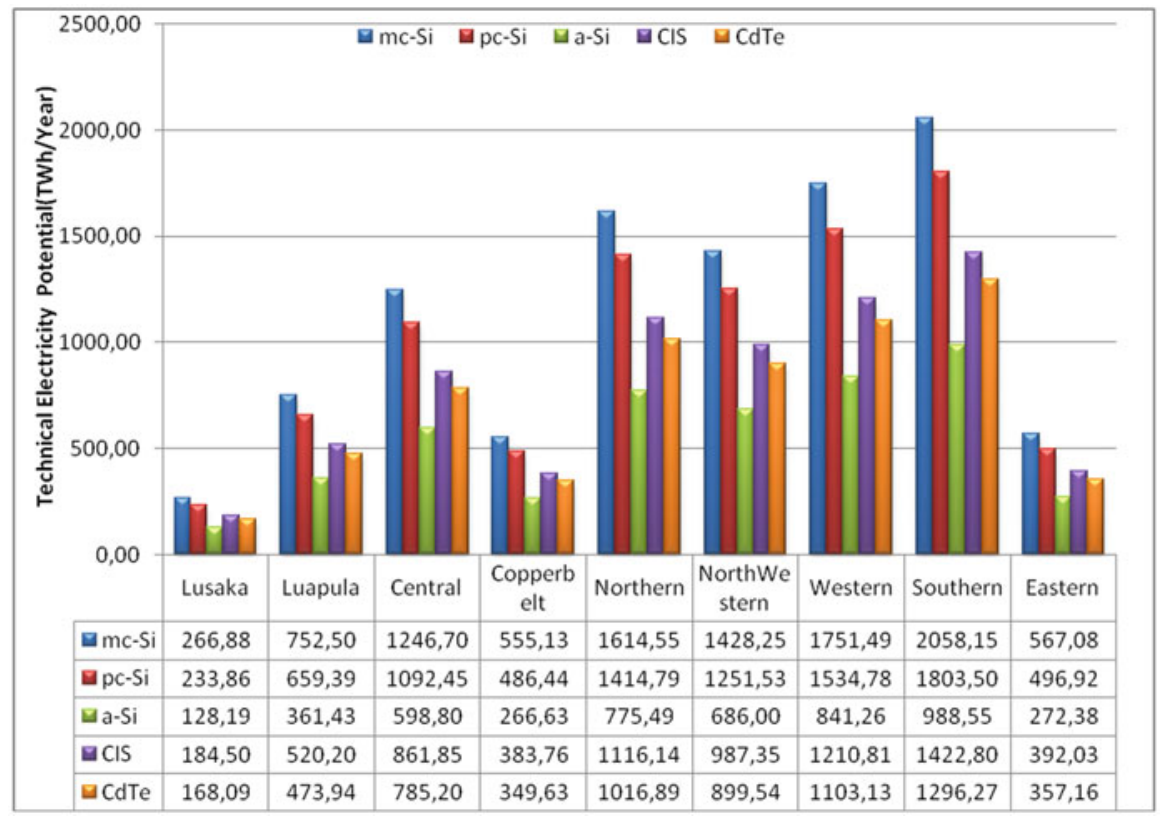

Fig. 19 Provincial solar PV technical electricity generation potential 
Table 11 District solar PV technical electricity generation potential by technology

\begin{tabular}{|c|c|c|c|c|c|c|}
\hline \multirow[b]{3}{*}{ Province } & \multirow{3}{*}{$\begin{array}{l}\text { Districts } \\
\text { sites }\end{array}$} & \multicolumn{5}{|c|}{ Technical electricity generation potential (TWh/Year) } \\
\hline & & \multicolumn{5}{|c|}{ Solar PV technologies } \\
\hline & & mc-Si & $\mathrm{pc}-\mathrm{Si}$ & $\mathrm{a}-\mathrm{Si}$ & CIS & $\mathrm{CdTe}$ \\
\hline \multirow[t]{8}{*}{ Eastern } & Chama & 181.69 & 159.21 & 87.27 & 125.60 & 114.43 \\
\hline & Chipata & 13.09 & 11.47 & 6.29 & 9.05 & 8.24 \\
\hline & Chadiza & 14.88 & 13.04 & 7.15 & 10.28 & 9.37 \\
\hline & Petauke & 122.33 & 107.19 & 58.76 & 84.57 & 77.05 \\
\hline & Katete & 33.77 & 29.59 & 16.22 & 23.35 & 21.27 \\
\hline & Lundazi & 26.32 & 23.07 & 12.64 & 18.20 & 16.58 \\
\hline & Nyimba & 134.85 & 118.17 & 64.77 & 93.22 & 84.93 \\
\hline & Mambwe & 40.15 & 35.18 & 19.29 & 27.76 & 25.29 \\
\hline Total & - & 567.08 & 496.92 & 272.38 & 392.03 & 357.16 \\
\hline \multirow[t]{4}{*}{ Lusaka } & Chongwe & 166.56 & 145.95 & 80.00 & 115.14 & 104.90 \\
\hline & Kafue & 72.91 & 63.89 & 35.02 & 50.41 & 45.92 \\
\hline & Luangwa & 25.19 & 22.07 & 12.10 & 17.41 & 15.87 \\
\hline & Lusaka & 2.22 & 1.94 & 1.07 & 1.53 & 1.40 \\
\hline Total & - & 266.88 & 233.86 & 128.19 & 184.50 & 168.09 \\
\hline \multirow[t]{11}{*}{ Southern } & Choma & 161.20 & 141.25 & 77.43 & 111.44 & 101.53 \\
\hline & Gwembwe & 59.30 & 51.96 & 28.48 & 40.99 & 37.35 \\
\hline & Itezhi-tezhi & 481.06 & 421.54 & 231.06 & 332.56 & 302.99 \\
\hline & Kalomo & 388.94 & 340.82 & 186.81 & 268.88 & 244.97 \\
\hline & Kazungula & 541.97 & 474.91 & 260.31 & 374.67 & 341.35 \\
\hline & Livingstone & 11.39 & 9.98 & 5.47 & 7.87 & 7.17 \\
\hline & Mazabuka & 138.02 & 120.94 & 66.29 & 95.41 & 86.93 \\
\hline & Monze & 84.08 & 73.68 & 40.39 & 58.13 & 52.96 \\
\hline & Namwala & 33.38 & 29.25 & 16.03 & 23.08 & 21.03 \\
\hline & Siavonga & 91.98 & 80.60 & 44.18 & 63.58 & 57.93 \\
\hline & Sinazongwe & 66.83 & 58.56 & 32.10 & 46.20 & 42.09 \\
\hline Total & - & $2,058.15$ & $1,803.50$ & 988.55 & $1,422.80$ & $1,296.27$ \\
\hline \multirow[t]{7}{*}{ Luapula } & Chienge & 24.27 & 21.27 & 11.66 & 16.78 & 15.28 \\
\hline & Kawambwa & 103.78 & 90.94 & 49.85 & 71.75 & 65.37 \\
\hline & Mansa & 297.66 & 260.83 & 142.97 & 205.77 & 187.47 \\
\hline & Milenge & 70.90 & 62.13 & 34.06 & 49.02 & 44.66 \\
\hline & Mwense & 97.39 & 85.34 & 46.78 & 67.32 & 61.34 \\
\hline & Nchelenge & 33.61 & 29.45 & 16.14 & 23.23 & 21.17 \\
\hline & Samfya & 124.89 & 109.44 & 59.99 & 86.34 & 78.66 \\
\hline Total & - & 752.50 & 659.39 & 361.43 & 520.20 & 473.94 \\
\hline \multirow[t]{7}{*}{ Northwestern } & Chavuma & 259.42 & 227.32 & 124.60 & 179.34 & 163.39 \\
\hline & Kabompo & 109.04 & 95.55 & 52.37 & 75.38 & 68.68 \\
\hline & Kasempa & 117.11 & 102.62 & 56.25 & 80.96 & 73.76 \\
\hline & Mufumbwe & 100.84 & 88.37 & 48.44 & 69.71 & 63.51 \\
\hline & Mwinilunga & 111.97 & 98.12 & 53.78 & 77.40 & 70.52 \\
\hline & Solwezi & 241.48 & 211.61 & 115.99 & 166.94 & 152.09 \\
\hline & Zambezi & 488.38 & 427.95 & 234.57 & 337.62 & 307.59 \\
\hline Total & - & $1,428.25$ & $1,251.53$ & 686.00 & 987.35 & 899.54 \\
\hline
\end{tabular}


Table 11 (continued)

\begin{tabular}{|c|c|c|c|c|c|c|}
\hline \multirow[b]{3}{*}{ Province } & \multirow{3}{*}{$\begin{array}{l}\text { Districts } \\
\text { sites }\end{array}$} & \multicolumn{5}{|c|}{ Technical electricity generation potential (TWh/Year) } \\
\hline & & \multicolumn{5}{|c|}{ Solar PV technologies } \\
\hline & & $\mathrm{mc}-\mathrm{Si}$ & pc-Si & a-Si & CIS & $\mathrm{CdTe}$ \\
\hline \multirow[t]{12}{*}{ Northern } & Chinsali & 76.34 & 66.90 & 36.67 & 52.77 & 48.08 \\
\hline & Chilubi & 23.03 & 20.18 & 11.06 & 15.92 & 14.51 \\
\hline & Isoka & 58.53 & 51.29 & 28.11 & 40.46 & 36.86 \\
\hline & Kaputa & 257.42 & 225.57 & 123.64 & 177.96 & 162.13 \\
\hline & Kasama & 142.65 & 125.00 & 68.51 & 98.61 & 89.84 \\
\hline & Luwingu & 129.37 & 113.36 & 62.14 & 89.43 & 81.48 \\
\hline & Mbala & 122.116 & 107.04 & 58.67 & 84.45 & 76.94 \\
\hline & Mpika & 316.173 & 277.54 & 152.13 & 218.96 & 199.48 \\
\hline & Mporokoso & 1851.59 & 162.63 & 89.14 & 128.30 & 116.89 \\
\hline & Mpulungu & 96.168 & 84.71 & 46.43 & 66.83 & 60.89 \\
\hline & Mungwi & 104.35 & 91.43 & 50.12 & 72.13 & 65.72 \\
\hline & Nakonde & 101.72 & 89.13 & 48.86 & 70.32 & 64.07 \\
\hline Total & - & $1,614.55$ & $1,414.79$ & 775.49 & $1,116.14$ & \begin{tabular}{|l|l|}
$1,016.89$ \\
\end{tabular} \\
\hline \multirow{3}{*}{ Province } & Districts & \multicolumn{5}{|c|}{ Technical electricity generation potential (TWh/year) } \\
\hline & & \multicolumn{5}{|c|}{ Solar PV technologies } \\
\hline & Sites & $\mathrm{Mc}-\mathrm{Si}$ & Pc-Si & $\mathrm{a}-\mathrm{Si}$ & CIS & $\mathrm{CdTe}$ \\
\hline \multirow[t]{6}{*}{ Central } & Chibombo & 173.19 & 151.76 & 83.18 & 119.72 & 109.08 \\
\hline & Kabwe & 11.76 & 10.31 & 5.65 & 8.13 & 7.41 \\
\hline & Kapiri-Mposhi & 197.08 & 172.70 & 94.66 & 136.24 & 124.13 \\
\hline & Mkushi & 225.45 & 197.56 & 108.29 & 155.86 & 142.00 \\
\hline & Mumbwa & 285.75 & 250.40 & 137.25 & 197.54 & 179.97 \\
\hline & Serenje & 353.46 & 309.73 & 169.77 & 244.35 & 222.62 \\
\hline Total & - & $1,246.70$ & $1,092.45$ & 598.80 & 861.85 & 785.20 \\
\hline \multirow[t]{10}{*}{ Copperbelt } & Chililabombwe & 17.45 & 15.29 & 8.38 & 12.06 & 10.99 \\
\hline & Chingola & 30.56 & 26.78 & 14.68 & 21.12 & 19.25 \\
\hline & Kalulushi & 22.25 & 19.49 & 10.69 & 15.38 & 14.01 \\
\hline & Kitwe & 23.89 & 20.94 & 11.48 & 16.52 & 15.05 \\
\hline & Luanshya & 19.11 & 16.75 & 9.18 & 13.21 & 12.04 \\
\hline & Lufwanyama & 155.09 & 135.90 & 74.49 & 107.22 & 97.68 \\
\hline & Masaiti & 90.62 & 79.41 & 43.53 & 62.64 & 57.07 \\
\hline & Mpongwe & 154.45 & 135.34 & 74.18 & 106.77 & 97.27 \\
\hline & Mufulira & 22.60 & 19.80 & 10.85 & 15.62 & 14.23 \\
\hline & Ndola & 19.11 & 16.75 & 9.18 & 13.21 & 12.04 \\
\hline Total & - & 555.13 & 486.44 & 266.63 & 383.76 & 349.63 \\
\hline \multirow[t]{8}{*}{ Western } & Kalabo & 526.33 & 461.21 & 252.80 & 363.85 & 331.50 \\
\hline & Kaoma & 134.31 & 117.69 & 64.51 & 92.85 & 84.59 \\
\hline & Lukulu & 407.79 & 357.33 & 195.86 & 281.90 & 256.83 \\
\hline & Mongu & 50.23 & 44.02 & 24.13 & 34.73 & 31.64 \\
\hline & Senanga & 179.73 & 157.49 & 86.33 & 124.25 & 113.20 \\
\hline & Sesheke & 254.36 & 222.89 & 122.17 & 175.84 & 160.21 \\
\hline & Shang'ombo & 198.74 & 174.15 & 95.46 & 137.39 & 125.17 \\
\hline & - & $1,751.49$ & $1,534.78$ & 841.26 & $1,210.81$ & $1,103.13$ \\
\hline Zambia & - & $10,240.73$ & $8,973.66$ & $4,918.72$ & $7,079.44$ & $6,449.86$ \\
\hline
\end{tabular}


Table 12 Provincial solar PV technical electricity generation potential by technology

\begin{tabular}{l|c|c|c|r|r}
\hline \multirow{2}{*}{ Provinces } & \multicolumn{5}{l}{ Technical Electricity Generation Potential (TWh/Year) } \\
\cline { 2 - 6 } & \multicolumn{2}{|l}{ Solar PV technologies } & \multicolumn{1}{l}{} \\
\cline { 2 - 6 } & mc-Si & pc-Si & a-Si & CIS & CdTe \\
\hline Lusaka & 266.88 & 233.86 & 128.19 & 184.50 & 168.09 \\
\hline Luapula & 752.50 & 659.39 & 361.43 & 520.20 & 473.94 \\
\hline Central & $1,246.70$ & $1,092.45$ & 598.80 & 861.85 & 785.20 \\
\hline Copperbelt & 555.13 & 486.44 & 266.63 & 383.76 & 349.63 \\
\hline Northern & $1,614.55$ & $1,414.79$ & 775.49 & $1,116.14$ & $1,016.89$ \\
\hline Northwestern & $1,428.25$ & $1,251.53$ & 686.00 & 987.35 & 899.54 \\
\hline Western & $1,751.49$ & $1,534.78$ & 841.26 & $1,210.81$ & $1,103.13$ \\
\hline Southern & $2,058.15$ & $1,803.50$ & 988.55 & $1,422.80$ & $1,296.27$ \\
\hline Eastern & 567.08 & 496.92 & 272.38 & 392.03 & 357.16 \\
\hline Zambia & $\mathbf{1 0 , 2 4 0 . 7 3}$ & $\mathbf{8 , 9 7 3 . 6 6}$ & $\mathbf{4 , 9 1 8 . 7 2}$ & $\mathbf{7 , 0 7 9 . 4 4}$ & $\mathbf{6 , 4 4 9 . 8 6}$ \\
\hline
\end{tabular}

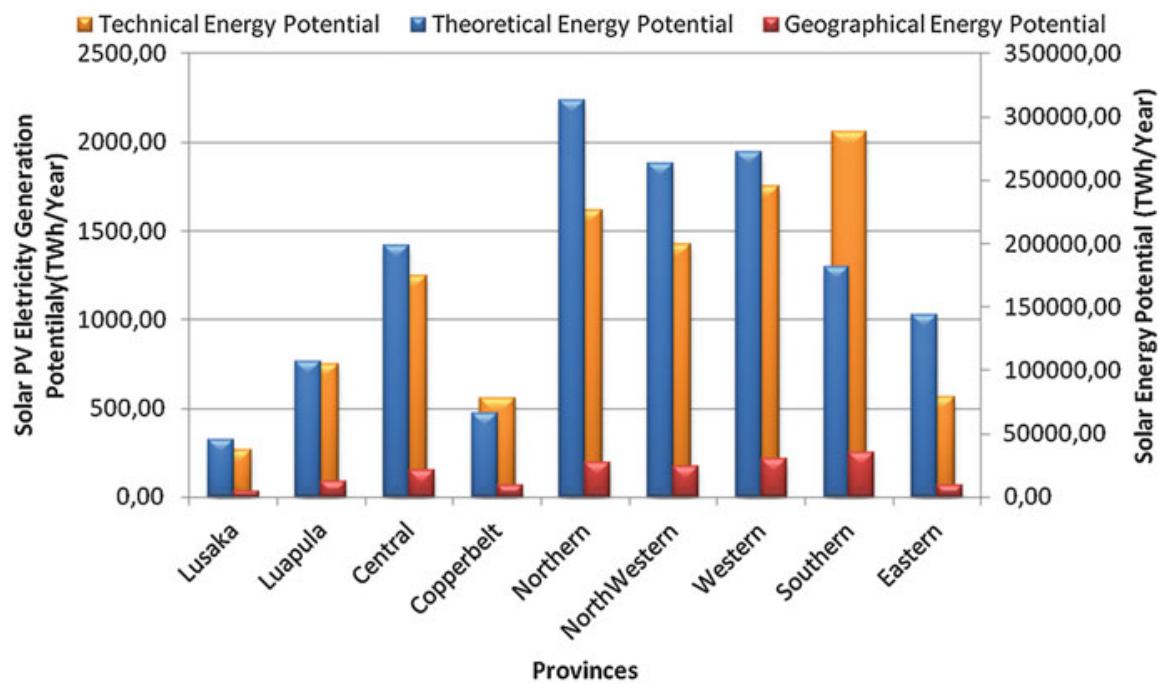

Fig. 20 Comparison of theoretical, geographical, and technical solar energy potential

While Zambia has abundance suitable areas (Fig. 14) and almost evenly distributed sunlight (Figs. 1 and 2) across the country, the focus on surface and suitable areas in the nine provinces and solar irradiation levels, the following can be identified. These factors however should be considered in the planning of national energy mix and also for management of electricity in the national grid once the penetration of solar PV technologies increases and becomes a significant part in the national electricity generation. 


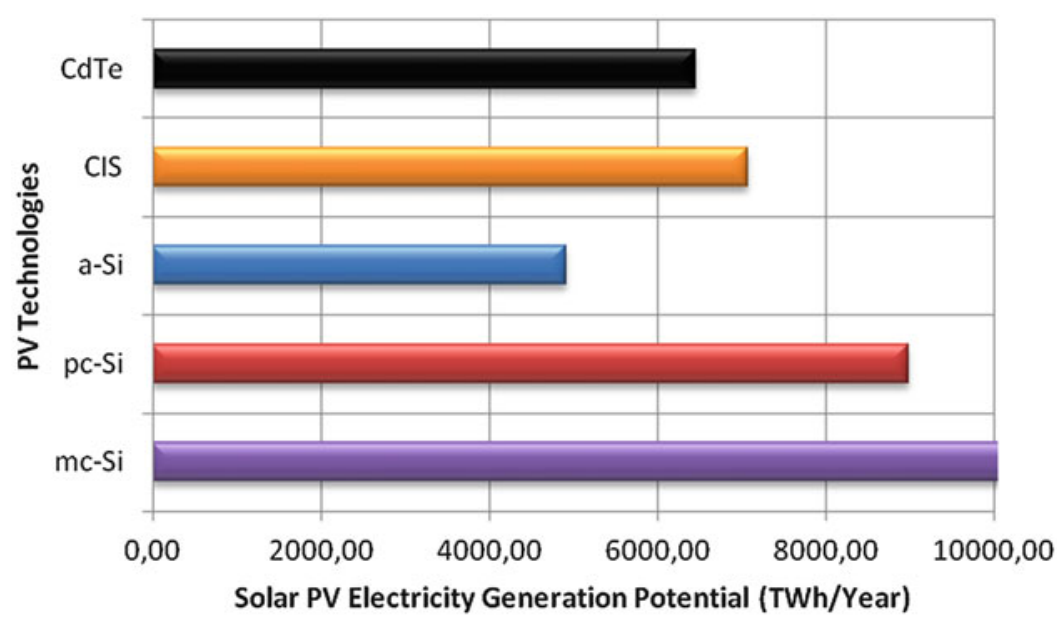

Fig. 21 Comparison of solar PV cell technologies electricity generation potential

- The highest theoretical solar energy potential is in Northern Province $(313,025.37 \mathrm{TWh} /$ year) due to large surface areas of the province.

- However, the highest geographical and technical solar energy potential for solar electricity generation is in Southern Province $(35,117.56 \mathrm{TWh} / \mathrm{year})$ due to large available suitable areas.

- From highest yield point of view, due to abundance of sunlight received by Western province $\left(5.89 \mathrm{kWh} / \mathrm{m}^{2}\right.$-day), the annual yields per installed solar PV systems peak are expected in Western province as compared to the rest of the country.

- Comparing the PV technologies, large electricity generation differences can be observed not only at district level but also at provincial levels. Table 13 indicates crystalline silicon based PV technologies have higher electricity generation potential as compared to thin film per square kilometer.

Table 13 summarizes the estimated solar PV technical electricity generation and solar PV power capacity potential in Zambia for each nine (9) provinces investigated in this chapter.

\section{Conclusion}

This chapter provides an approach for identifying and mapping the potential sites for sustainable development of solar PV technologies based power plants using GIS spatial analysis. The chapter has integrated the geographical and technological factors as well as the Laws of Zambia on environmental protection and pollution control legislative framework for evaluating the electricity generation potential and feasible sites suitable for sustainable PV systems deployment across Zambia. 


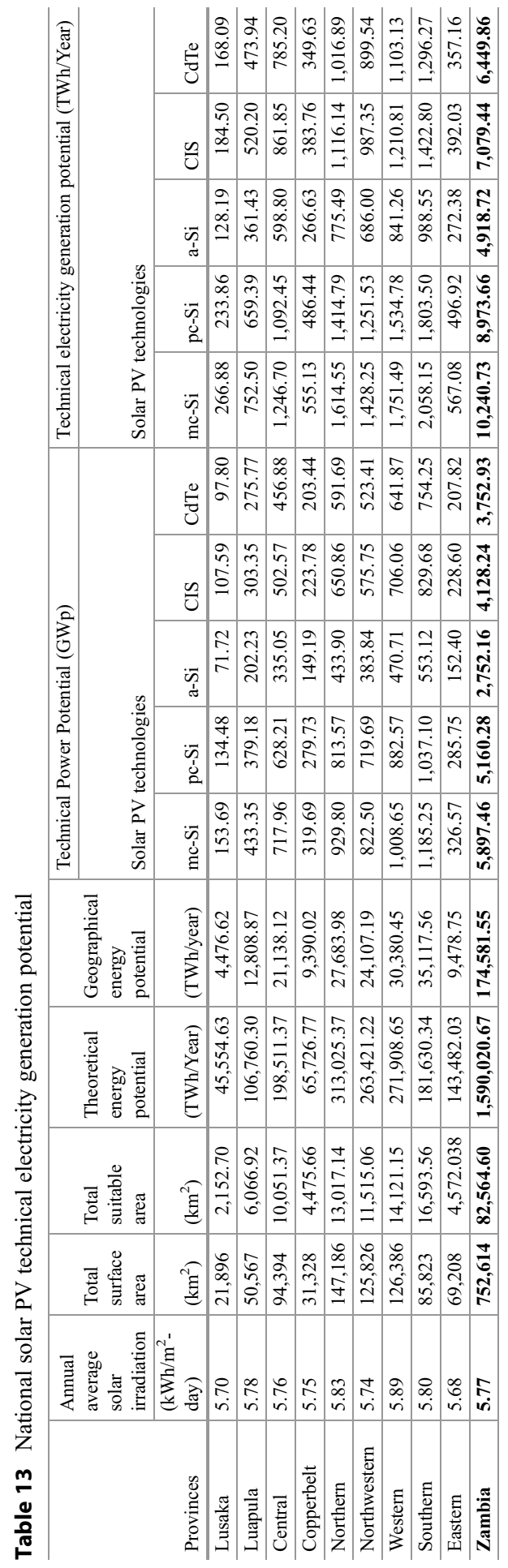


Thus, this chapter shows that Zambia has vast available solar energy technical potential for PV electricity generation. The larger PV electricity generation potential variability at district and provincial level is highly linked with the local geographical features and terrain which affect the availability of suitable area and also local solar energy resource. Therefore, integration and generation of electricity from PV systems has greater potential to mitigate the current energy shortage and increase access to energy for all in Zambia. Furthermore, the suitable land areas in almost all districts and provinces is large enough for solar energy harvesting at utility-scale PV system capable of covering the present and future total electricity demands for Zambia. The identified potential sites have a total of available suitable area of $82,564.601 \mathrm{~km}^{2}$ representing $10.97 \%$ of Zambia's total surface area equivalent to $5,897.46 \mathrm{GW}$ technical power potential. This translates to $10,240.73 \mathrm{TWh} /$ year electricity generation potential considering annual average solar irradiation of $5.78 \mathrm{kWh} / \mathrm{m}^{2}$-day and monocrystalline silicon solar PV technology mounted at optimal tilt angle. This potential has capacity to reduce $\mathrm{CO}_{2}$ emission and contribute to achieve energy access for all and Sustainable Development Goals (SDGs).

The identification of potential sites and solar energy potential analysis will help improve the understanding of the potential solar energy, and PV technology can contribute to achieving sustainable national energy mix and increasing energy access for all in Zambia. Furthermore, it will help the government in setting up tangible energy targets and effective integration of solar PV systems into national energy mix. Hence, it is hoped that the suitability map established and the technical potential evaluated will help guide the decision makers and also the investors for planning future electricity generation targets and investment across the country and achieve the 2030 development goals.

\section{References}

Abdolvahhab Fetanat EK (2015) A novel hybrid MCDM approach for offshore wind farm site selection: a case study of Iran. Ocean Coast Manag 109:17-28. https://doi.org/10.1016/j. ocecoaman.2015.02.005

Addisu D, and Mekonnen PV (2015) A web-based participatory GIS (PGIS) for offshore wind farm suitability within Lake Erie, Ohio. Renew Sust Energ Rev 41:162-177. https://doi.org/10.1016/ j.rser.2014.08.030, ScienceDirect

Ahmed Aly SS (2017) Solar power potential of Tanzania: identifying CSP and PV hot spots through a GIS multicriteria decision making analysis. Renew Energy 113:159-175. https://doi.org/10. 1016/j.renene.2017.05.077, ScienceDirect

Ahmed HHA et al (2017) Energy performance, environmental impact, and cost assessment for a photovoltaic plant under Kuwait climate condition. Sustainable Energy technologies \& Assessments 22:25-33

Alami Merrouni A, Mezrhab A, Mezrhab A (2014) CSP sites suitability analysis in the eastern region of Morocco. Energy Procedia 49:2270-2279. https://doi.org/10.1016/j.egypro.2014.03. 240

Ali HM, Hojabri M, Hamada HM, Samsuri FB, Ahmed MN (2016) Performance evaluation of two PV technologies (c-Si and CIS) for building integrated photovoltaic based on tropical climate condition: a case study in Malaysia, energy and buildings. http://dxdoi.org/10.1016/j.enbuild. 2016.03.052 
Aly Sanoh AS (2014) The economics of clean energy resource development and grid interconnection in Africa. Renew Energy 62:599-609. https://doi.org/10.1016/j.renene.2013.09.017, ScienceDirect

Anthony Lopez BR (2012) U.S. renewable energy technical potentials: a GIS based analysis. NREL, U.S. Department of Energy. National Renewable Energy Laboratory (NREL, Colorado. NREL/TP-6A20-51946

Arthur Bossavy RG (2016) Sensitivity analysis in the technical potential assessment of onshore wind and ground solar photovoltaic power resources at regional scale. Appl Energy 182:145153. https://doi.org/10.1016/j.apenergy.2016.08.075

Ayompe LD (2014) An assessment of the energy generation potential of photovoltaic systems in Cameroon using satellite-derived solar radiation datasets. Sustainable Energy Technologies and Assessments 7:257-264

Bowa CM (2017) Solar photovoltaic energy progress in Zambia: a review. SAUPEC 2017, 25th Southern African Universities Power Engineering Conference, 30 January-01 February, 2017. Stellenbosch, South Africa: SAUPEC 2017

Brewer JR (2014) Solar PV site suitability using GIS analytics to evaluate utility scale solar power potential in the U.S: South West Region. Department of Civil and Environmental Engineering. Brigham: Brigham Young University. Retrieved April 2017

British Standard (1998) Photovoltaic system performance monitoring, guidelines for measurement, data exchange and analysis:BS EN 61724:1998, IEC 61724: 1998. BSI 05.1999, British Standard

Chao-Rong Chen C-CH-J (2014) Ahybrid MCDM model for improving GIS-based solar farms site selection. (C.-S. Jwo, Ed.) International Journal of Photoenergy:1-9. https://doi.org/10.1155/ 2014/925370

Charabi Y, and Gastli A (2011) PV site suitability analysis using GIS-based spatial fuzzy multi criteria evaluation. Renew Energy 36:2554-2561. https://doi.org/10.1016/j.renene.2010.10. 037, ScienceDirect

Chinairn (2013) Photovoltaic industry: abandoned projects on the plateau. Chinairn. Retrieved January 2016, from http://www.chinairn.com/print/3042250.html

Damon T, and Vasilis F (2011) Environmental impacts from the installation and operation of largescale solar power plants. Renew Sust Energ Rev 15:3261-3270

Didler TG (2012) The RETScreen model for assessing potential of PV projects. RETScreen

England, N (2011) Solar Parks: maximising environmental benefits. Natural England

Fylladitakis E (2015) Environmental impacts of photovoltaic systems. Brunel University, London

Gauri SS (2013) Zambia renewable readiness assessment. International Renewable Energy Agency (IRENA), Lusaka

Geoffrey TK, and Tidwell VC (2013) Water use and supply concerns for utility-scale solar projects in the southwestern United States. Sandia National Laboratories, Livermore

Gipe P (1995) Wind energy comes of age. Wiley, New York

Interior Department, U (2010) Impacts of solar energy development and potential mitigation measures. I Draft solar programmatic environmental impact statement, vol 1, pp 1-302. N/A: Federal Register. Accessed in July 2017

IRENA (2012) Renewable energy technologies: cost analysis series volume1: power sector issue4/ 5. International Renewable Energy Agency (IRENA) working Paper

IRENA (2013) Zambia renewable readiness assessment 2013. International Renewable Energy Agency (IRENA), Lusaka

Ivan PR (2015) Analysis of insolation potential of Knjazevac Municipality (Serbia) using multicriteria approach. Renewable and Sustainable Energy Review

Janke JR (2010) Multicriteria GIS modeling of wind and solar farms in Colorado. Renew Energy 35:2228-2234. https://doi.org/10.1016/j.renene.2010.03.014. ScienceDirect

Joss JW, and Watson MD (2015) Regional scale wind farm and solar farm suitability assessment using GIS-assisted multi-criteria evaluation. Landsc Urban Plan 138:20-31. https://doi.org/10. 1016/j.landplan.2015.02.001. ScienceDirect 
Kaoshan D et al (2015) Environmental issues associated with wind energy-a review. Renew Energy 75:911-921. https://doi.org/10.1016/j.renene.2014.10.074

Kynakis EK (2009) Performance analysis of a grid connected photovoltaic park on the island of Crete. Energy Convers Manag 50(3):433-438

Lopez AR (2012) U.S renewable energy technical potentials: a GIS-based analysis. Technical Report NREL/TP-6A20-5146, United States

Marcos Rodriques CM (2010) A method for the assessment of the visual impact caused by the large scale deployment of renewable energy facilities. Environ Impact Assess Rev 30:240-246. https://doi.org/10.1016/j.eiar.2009.10.004

Martin-Chivelet N (2016) Photovoltaic potential and land use estimation methodology. Energy 94: 233-242. https://doi.org/10.1016/j.energy.2015.10.108

Ming ZS (2015) Is the "Sun" still hot in China? The study of the present situation, problems and trends of the photovoltaic industry in China. Renew Sust Energ Rev 23:1224-1237

MMEWD (2008) National energy policy. Ministry of Mines, Energy and Water Development of Zambia, (MMEWD), Lusaka

Mwanza M, et al. (2016a) Assessment of solar energy source distribution and potential in Zambia. ISEM2016, 3rd international symposium on environment and morality, 4-5 November 2016. Alanya-Turkey: ISEM2016

Mwanza M, et al. (2016b) The potential of solar energy for sustainable water resource development and averting national social burden in rural areas of Zambia. ISEM2016, 3rd international symposium on environment and morality, 4-6 November 2016. Alanya-Turkey: ISEM2016

Nazli Yonca A (2010) GIS-based environmental assessment of wind energy systems for spatial planning: a case study from western Turkey. Renewable and Sustainable Energy Review 14:364-373. https://doi.org/10.1016/j.rser.2009.07.023. ScienceDirect

Quansah DA (2016) Solar photovoltaics in sub-Saharan Africa-addressing barriers, unlocking potential. Energy Economics Iberian Conference (Energy Procedia) 106:97-110. Lisbon, Portugal: ELSEVIER, ScienceDirect. https://doi.org/10.1016/j.egypro.2016.12.108

Robert CD (2014) Using the sun to decarbonize the power sector: the economic potential of photovoltaics and concentrating solar power. Appl Energy 135:704-720

Ronald CE (2016) GIS-based multi-criteria decision analysis in natural resource management. GISBased Multi-Criteria Decision Analysis. University of Tsukuba

Saidur R, Rahim NA, Islam MR, Solangi KH (2011) Environmental impact of wind energy. Renew Sust Energ Rev 15(5):2423-2430. Accessed in July 2017

Samuel AS, and Owusu PA (2016). A review of Ghana's energy sector national energy statistics and policy framework. Civil Environ Eng:1-27. Retrieved January 2017

Sanchez Lozano JM et al (2013) Geographical information system (GIS) and multi criteria decision making (MCDM) methods for the evaluation of solar farms locations: case study in south eastern Spain. Renewable and Sustainable Energy Review 24:544-556. https://doi.org/10.1016/ j.rser.2013.03.019. ScienceDirect

Sanchez-Lozano JM, and García-Cascales MS (2014). Identification and selection of potential sites for onshore wind farms development in region of Murcia, Spain. Energy, 73(-), 311-324. https://doi.org/10.1016/j.energy.2014.06.024. ScienceDirect

SEFI/UNEP (2009) Global trends in sustainable energy investment (online). SEFI/UNEP. Retrieved from http://sefi.unep.org/english/globaltrends2009.html;

Shifeng W, and Sicong W (2015) Impact of wind energy on environment; a review. Renew Sust Energ Rev 49:437-443. https://doi.org/10.1016/j.rser.2015.04.137

Siheng W et al (2016) Selecting photovoltaic generation sites in Tibet using remote sensing and geographic analysis. Sol Energy 133:85-93. https://doi.org/10.1016/j.solener.2016.03.069. ScienceDirect

Siyasankari S, and Babu JSC (2015) Performance evaluation and validation of $5 \mathrm{MW}_{\mathrm{P}}$ grid connected solar photovoltaic plant in South India. Energy Convers Manag 100(2015):429439, ScienceDirect 
Suprava C. \& Pradip K.S., (2015), Technical mapping of solar photovoltaic for the coal city of india, Renewables: Wind, Water, and Solar (2015) 2:11, DOI 10.1186/s40807-015-0013-1

Suri DQ (2005) PV-GIS: a web-based solar radiation database for the calculation of PV potential in Europe. International Journal of Sustainable Energy 24:55-67

The Environmental Council of Zambia (1994) Chapter 204 of the Laws of Zambia, the environmental protection and pollution control act. Ministry of Legal Affairs, Government of the Republic of Zambia, Lusaka

Tripathi B, Yadav P, Rathod S, Kumar M (2014) Performance analysis and comparison of two silicon material based photovoltaic technologies under actual climatic conditions in Western India. Energy Convers Manag 80:97-102

Tsoutsos T, et al (2005) Environmental impacts from the solar energy technologies. Energy Policy 33:289-296

Tsoutsos T et al (2009) Visual impact evaluation of a wind park in a Greek Island. Appl Energy 86: $546-553$

Turlough G (2017) A case study identifying and mitigating the environmental and community impacts from construction of a utility-scale solar photovoltaic power plant in eastern Australia. Sol Energy 146:94-104

U.S. (2016). www.energy.gov. Retrieved November 2016, from Office of Energy Efficiency \& Renewable Energy

Union of Concerned Scientists (2015) Environmental impacts of renewable energy technologies. Accessed in August, 2016 from Union of Concerned Scientists: Science for a healthy planet and safer world: www.ucsusa.org/clean-energy/renewable-energy/environmental-impacts\#bf-toc-0

Uyan Mevlut (2013) GIS-based solar farms site selection using analytic hierarchy process in Karapinar region, Konya/Turkey. Energy. Renewable and Sustainable Energy Review 28:1117. https://doi.org/10.1016/j.rser.2013.07.042. ScienceDirect

Walimwipi HS (2012) Investment incentives for renewable energy in southern Africa: case study of Zambia. International Institute for Sustainable Development (IISD), Lusaka

Wang C, and Prinn RG (2010) Potential climate impacts and reliability of a very large-scale wind farm. Atmospheric Chemical and Physical 10:2053-2061

Yan-wei SA (2013) GIS-based approach for potential analysis of solarPV generation at the regional scale: a case study of Fujian Province. Energy Policy 58:248-259

Yassine CA (2011) PV site suitability analysis using GIS-based spatial fuzzy multi-criteria evaluation. Renew Energy 36:2554-2561

Yassine C, and Adel G (2012) Spatio-temporal assessment of dust risk maps for solar energy system using proxy data. Renew Energy 44:23-31. https://doi.org/10.1016/j.renene.2011.12.005, ScienceDirect

Open Access This chapter is licensed under the terms of the Creative Commons Attribution 4.0 International License (http://creativecommons.org/licenses/by/4.0/), which permits use, sharing, adaptation, distribution and reproduction in any medium or format, as long as you give appropriate credit to the original author(s) and the source, provide a link to the Creative Commons license and indicate if changes were made.

The images or other third party material in this chapter are included in the chapter's Creative Commons license, unless indicated otherwise in a credit line to the material. If material is not included in the chapter's Creative Commons license and your intended use is not permitted by statutory regulation or exceeds the permitted use, you will need to obtain permission directly from the copyright holder.

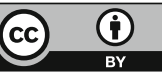

